\title{
Citrus leprosis virus N: A New Dichorhavirus Causing Citrus Leprosis Disease
}

\author{
Pedro Luis Ramos-González, Camila Chabi-Jesus, Orlene Guerra-Peraza, Aline Daniele Tassi, Elliot Watanabe Kitajima, \\ Ricardo Harakava, Renato Barbosa Salaroli, and Juliana Freitas-Astúa
}

First, second, third, sixth, and eighth authors: Lab. Bioquímica Fitopatológica, Instituto Biológico, São Paulo 04014-002, Brazil; second, fourth, fifth, and seventh authors: Escola Superior de Agricultura Luiz de Queiroz, Universidade de São Paulo, Piracicaba, São Paulo 13418-900, Brazil; third author: Citrus Research \& Education Center, University of Florida, Lake Alfred 33850; and eighth author: Embrapa Mandioca e Fruticultura, Cruz das Almas, Bahia 44380-000, Brazil.

Accepted for publication 31 March 2017.

\begin{abstract}
Citrus leprosis (CL) is a viral disease endemic to the Western Hemisphere that produces local necrotic and chlorotic lesions on leaves, branches, and fruit and causes serious yield reduction in citrus orchards. Samples of sweet orange (Citrus $\times$ sinensis) trees showing CL symptoms were collected during a survey in noncommercial citrus areas in the southeast region of Brazil in 2013 to 2016. Transmission electron microscopy analyses of foliar lesions confirmed the presence of rod-like viral particles commonly associated with CL in the nucleus and cytoplasm of infected cells. However, every attempt to identify these particles by reverse-transcription polymerase chain reaction tests failed, even though all described primers for the detection of known CL-causing cileviruses and dichorhaviruses were used. Next-generation sequencing of total RNA extracts from three symptomatic samples revealed the genome of distinct, although highly related $(>92 \%$ nucleotide sequence identity), viruses whose genetic organization is similar

to that of dichorhaviruses. The genome sequence of these viruses showed $<62 \%$ nucleotide sequence identity with those of orchid fleck virus and coffee ringspot virus. Globally, the deduced amino acid sequences of the open reading frames they encode share 32.7 to $63.8 \%$ identity with the proteins of the dichorhavirids. Mites collected from both the naturally infected citrus trees and those used for the transmission of one of the characterized isolates to Arabidopsis plants were anatomically recognized as Brevipalpus phoenicis sensu stricto. Molecular and biological features indicate that the identified viruses belong to a new species of CL-associated dichorhavirus, which we propose to call Citrus leprosis $\mathrm{N}$ dichorhavirus. Our results, while emphasizing the increasing diversity of viruses causing CL disease, lead to a reevaluation of the nomenclature of those viruses assigned to the genus Dichorhavirus. In this regard, a comprehensive discussion is presented.
\end{abstract}

Citrus leprosis (CL) is a nonsystemic disease caused by a heterogenic group of RNA viruses endemic to the Western Hemisphere (Bastianel et al. 2010; Roy et al. 2015a). The disease is characterized by necrotic or chlorotic spots in leaves, branches, and fruit, which progressively leads to the early drop of leaves and fruit, branch dieback, and, occasionally, to the death, predominantly, of the youngest citrus trees. Yield reduction of the infected orchards and costs to prevent or manage the CL infection foci make the disease a determinant economic burden to the citrus industry wherever it occurs.

CL-causing viruses belong to three distinguishing genera: Cilevirus (bipartite positive-sense [+] single-stranded RNA [ssRNA]), Higrevirus (tripartite [+]ssRNA), and Dichorhavirus (bipartite negativesense [-]ssRNA, family Rhabdoviridae, order Mononegavirales) (Afonso et al. 2016; Dietzgen et al. 2014; Locali-Fabris et al. 2012; Melzer et al. 2012). Viroplasms of such viruses occur in either the cytoplasm (for cileviruses and higreviruses) or the nucleus (for dichorhaviruses) of the infected plant cells, resulting in the wonted subclassification of CL in the types CL-cytoplasmic (CL-C) and CL-nuclear (CL-N).

Most of the CL reports confirmed by sequencing or reversetranscription polymerase chain reaction (RT-PCR) are of the type

Corresponding author: J. Freitas-Astua;

E-mail address: juliana.astua@embrapa.br

P. L. Ramos-González and C. Chabi-Jesus have contributed equally to this work.

*The $\boldsymbol{e}$-Xtra logo stands for "electronic extra" and indicates that one supplementary figure and four supplementary tables are published online.

(c) 2017 The American Phytopathological Society
CL-C, particularly of cileviruses (Bastianel et al. 2010; León et al. 2014; Ramos-González et al. 2016a; Roy et al. 2013a), and, less frequently, type CL-N, which has been only detected in restricted areas in Mexico and Colombia (Roy et al. 2014, 2015b). Incidence of CL-N was also reported a few decades ago in some cool-weather localities in Brazil and in higher elevations in Panama, although the diagnosis was only based on the morphology of the observed virions and the apparent cytopathic effects in transmission electron microscopy (TEM) analyses (Chagas et al. 2006; de Dominguez et al. 2001; Freitas-Astúa et al. 2004; Kitajima et al. 1972, 2004). It is likely that CL-N was also the cause of successive leprosis epidemics that severely affected citrus orchards in Florida in the United States, mostly during the 1920s and 1930s until the mid-20th century (Hartung et al. 2015; Kitajima et al. 2011). However, due to several freezes and intense sulfur applications to control the mite vector, CL disappeared from that state in the 1960s and, despite careful surveys, it has not been reported in the United States since (Childers et al. 2003a).

Dichorhaviruses such as orchid fleck virus (OFV, type member of the genus), have short, rod-like nonenveloped particles (40 to 50 by 100 to $110 \mathrm{~nm}$ ) and encapsidate two (-)ssRNA molecules that are template for transcription of monocistronic polyadenylated messenger RNA (mRNA) for the expression of six viral proteins (Kondo et al. 2006). As for rhabdoviruses, contiguous transcriptional units in OFV are separated by nontranscribed stretches of a few nucleotides known as intergenic (IG) sequences. These IG sequences are delimited by the gene start sequences and the polyadenylation signals of the flanking open reading frames (ORF) (Jackson et al. 2005; Kondo et al. 2014). RNA1 (approximately 6.4 $\mathrm{kb}$ ) of OFV isolate orchid (OFV-orchid) harbors the information for the nucleocapsid protein (gene $N, \mathrm{ORF} 1$ ) and four other putative 
proteins identified as phosphoprotein (gene $P$, ORF2), movement protein (gene $M P$, ORF3), matrix protein (gene $M, \mathrm{ORF} 4$ ), and glycoprotein (gene $G$, ORF5). Its RNA2 (approximately $6.0 \mathrm{~kb}$ ) encodes the RNA-dependent RNA polymerase (gene $L$, ORF6) (Kondo et al. 2006). Each genomic RNA of OFV-orchid ends in untranslated extragenic regions (UTR) in the $3^{\prime}$ and $5^{\prime}$ termini called leader and trailer, respectively. During the infection, leader regions from both genomic RNA are transcribed into polyadenylated short transcripts (Kondo et al. 2014).

The genomes of two OFV isolates that cause CL-N were fully characterized. First named as Citrus leprosis virus nuclear type (Roy et al. 2015b) and Citrus necrotic spot virus (Cruz-Jaramillo et al. 2014), these viruses were further reclassified as strains of OFV, as indicated in the newest taxonomic report of the order Mononegavirales (Afonso et al. 2016). Globally, the genome of the OFV-orchid and those from the citrus-infecting isolates (OFV-citrus) show 90 to 91\% nucleotide sequence identity, whereas the citrus isolates share nucleotide sequence identity values higher than $96 \%$ (Cruz-Jaramillo et al. 2014; Roy et al. 2015a). Nevertheless, historically, CL-N has not been restricted to infections by OFV strains. Sequences recovered from herbarium specimens of CL-symptomatic tissues collected in Florida in 1948 showed the existence of a presumably extinguished virus that would represent a novel dichorhavirus related to but different from the currently circulating strains of OFV (Hartung et al. 2015).

The host range of OFV-orchid comprises at least 50 orchid species and several other nonorchid plants following mechanical transmission, which include the rutaceae Citrus hassaku Hort. ex Tanaka (Kondo et al. 2003). OFV recovered from orchid is persistently transmitted by nymphs and adults of the false-spider mite species Brevipalpus californicus (Acari: Tenuipalpidae) (Kondo et al. 2003). Isolates of OFV-citrus found in Mexico and Colombia naturally infect several citrus species, among them grapefruit (Citrus $\times$ paradise Macfadyen), lemon (Citrus $\times$ limon (L.) Burm. F.), lime (C. aurantiifolia (Christm.) Swingle), mandarin (C. reticulata Blanco), sour orange (C. aurantium L.), sweet or navel lime (C. limetta), sweet orange (Citrus $\times$ sinensis (L.) Osbeck), and Persian lime (Citrus $\times$ latifolia Tanaka); however, there is no evidence that these isolates can infect any orchid species (Cruz-Jaramillo et al. 2014; Roy et al. 2015a,b). Although confirmatory tests remain to be conducted, current evidence indicates that isolates of OFV-citrus are transmitted by B. californicus (Roy et al. 2015a). Transmission experiments also indicated that $B$. californicus and B. obovatus acted as vectors of the putative dichorhavirus responsible for CL-N that affected the citrus orchards in Florida decades ago (Knorr 1968), although only the presence of B. californicus could be confirmed in the voucher specimens collected by Knorr when they were later reexamined (Childers et al. 2003a).

In this work, we characterized viral isolates that were collected from sweet orange trees exhibiting CL symptoms in the State of São Paulo (SP), Brazil. These specimens became of particular interest because dichorhavirus-like particles detected in the infected tissues by TEM were negative in RT-PCR tests using a set of specific primers for the detection of OFV isolates citrus and orchid, and because no B. californicus was found on the infected plants. Nextgeneration sequencing (NGS) of the poly (A)-enriched fraction from three infected citrus plants and bioinformatics analyses revealed that the sequenced genomes represent isolates of a new dichorhavirus, whose RNA1 and RNA2 show 53.2 and $60.4 \%$ nucleotide sequence identity, respectively, with the cognates from OFV-orchid. Viral transmission to sweet orange and Arabidopsis thaliana (L.) Heynh. plants allowed identification of B. phoenicis sensu stricto as a vector of the new CL-causing virus.

Finally, we provide several reasons to claim the use of the name citrus leprosis virus $\mathrm{N}$ and the corresponding acronym CiLV-N to call the CL-associated dichorhaviruses that are currently circulating in the field using citrus as primary plant host. Consequently, we propose the creation of the species Citrus leprosis $\mathrm{N}$ dichorhavirus to assign the molecular variants of CiLV-N.

\section{MATERIALS AND METHODS}

Biological materials. Leaf samples from sweet orange (Citrus $\times$ sinensis (L.) Osbeck) trees showing typical CL symptoms (small bright-yellow lesions with a necrotic spot in the center) (Fig. 1) were collected in backyard orchards of São Bento do Sapucaí (SBS)

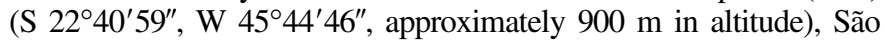
Roque (SRq) (S $23^{\circ} 53^{\prime} 50^{\prime \prime}, \mathrm{W} 47^{\circ} 11^{\prime} 92^{\prime \prime}$, approximately $800 \mathrm{~m}$ in

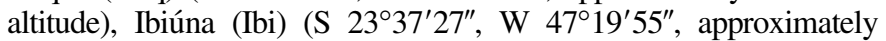
$1,000 \mathrm{~m}$ in altitude), and Monte Alegre do Sul (MAS) (S 22 $41^{\prime} 48^{\prime \prime}$, W 46 $38^{\prime} 10^{\prime \prime}$, approximately $800 \mathrm{~m}$ in altitude) counties in SP, Brazil, during 2013 to 2016. SBS and MAS are located north of São Paulo City, while Ibi and SRq are located west of the city, at $20 \mathrm{~km}$ from one another and approximately 130 to $170 \mathrm{~km}$ away from SBS and MAS. Sweet orange samples from Amparo, SP, Brazil (S 22 $42^{\prime} 11^{\prime \prime}$, W 4645'54", approximately $674 \mathrm{~m}$ in altitude) and Serra Negra, SP, Brazil (S $22^{\circ} 36^{\prime} 44^{\prime \prime}, \mathrm{W} 46^{\circ} 42^{\prime} 02^{\prime \prime}$, approximately $925 \mathrm{~m}$ in altitude) with similar CL-N symptoms were used in the validation of the RT-PCRbased diagnostic method. Small pieces of symptomatic tissue were prefixed for at least $2 \mathrm{~h}$ in a modified Karnovsky solution $(2.5 \%$ glutaraldehyde and $2 \%$ paraformaldehyde in $0.05 \mathrm{M}$ cacodylate buffer, $\mathrm{pH}$ 7.2) for further TEM analyses (Kitajima and Nome 1999). The rest were kept at $-80^{\circ} \mathrm{C}$ for RNA extraction. For taxonomic analysis, fieldcollected Brevipalpus mite samples were fixed in a $70 \%$ ethanol solution. Some mites were kept alive for viral transmission experiments.

TEM analyses. Symptomatic leaf samples were postfixed in a solution of $\mathrm{OsO}_{4}(1 \%)$ for $1 \mathrm{~h}$, dehydrated in acetone, infiltrated, and embedded in the low-viscosity Spurr's epoxy resin. Blocks were sectioned in a Leica Ultracut C ultramicrotome (Vienna) equipped with a Diatome Diamond knife (Biel, Switzerland). Sections were mounted on 300-mesh copper grids, stained with 3\% uranyl acetate and Reynold's lead citrate, and examined in a Zeiss EM 900 (Carl Zeiss AG, Oberkochen, Germany) or a JEOL JEM 1011 (JEOL, Akishima, Japan) transmission electron microscope and images were digitally recorded. Longitudinally or cross-sectioned rod-like particles from each sample were measured to evaluate their dimensions.

RNA extraction and RT-PCR detection of CL-associated viruses. Small fragments of leaf tissues with CL lesions were ground to powder with mortar and pestle using liquid nitrogen. Total RNA was extracted using Trizol Reagent (Life Technologies, Foster City, CA) and cDNA was generated from $500 \mathrm{ng}$ of RNA extracts using random primers following the manufacturer's recommendations for the RevertAid H Minus First-Strand cDNA Synthesis Kit (Thermo Scientific, Madison, WI). cDNA solutions $(3 \mu \mathrm{l})$ were assayed in independent PCR assays for the specific detection of citrus leprosis virus $\mathrm{C}$ (CiLV-C), citrus leprosis virus cytoplasmic type 2 (CiLV-C2), and OFV-orchid (Kubo et al. 2009; Locali et al. 2003; Roy et al. 2014, 2013a). Moreover, degenerate primers for the detection of the $L$ gene (RNA2) from OFV were also used (RamosGonzález et al. 2016b) (Supplementary Table S1).

Viral genome sequencing. Tissue fragments $(500 \mathrm{mg})$ showing CL lesions were removed from sweet orange leaves collected in SBS, Ibi, and SRq localities. Each source was independently processed and their RNA extracts were obtained as described above. RNA extracts were further purified using the RNeasy Mini Kit (Qiagen, Venlo, The Netherlands). RNA quantification and ratios of absorbance at 260/280 $\mathrm{nm}$ were estimated using a NanoDrop ND-8000 microspectrophotometer (Thermo Scientific, Waltham, MA). RNA samples were sent to the Animal Biotech Laboratory, Escola Superior de Agricultura Luiz de Queiroz, University of São Paulo, (Piracicaba, SP, Brazil) for sequencing using HiSeq 2500 Technology. Library preparation and paired sequencing $(2 \times 125 \mathrm{bp})$ were carried out using the Illumina TruSeq Stranded mRNA Library Prep Kit and HiSeq SBS v4 High-Output Kit, respectively (Illumina, San Diego, CA). Reads were assembled de novo, using the RNA-Seq assembler Shannon (Kannan et al. 2016). Genomic scaffolds were the base to prepare a set of 19 primer pairs using Primer3 software (Untergasser et al. 2012) (Supplementary Table S2). Overlapping 
fragments were amplified using Taq DNA polymerase and subsequently sequenced by the Sanger method to confirm the NGS data. $5^{\prime}$ and $3^{\prime}$ termini of genomic RNA from the three isolates were determined by rapid amplification of cDNA ends (RACE) using the corresponding primers and following the manufacturer's recommendations for the SMARTer RACE 5'/3' Kit (Clontech Laboratories, Mountain View, CA). All generated amplicons were cloned and at least five independent clones were sequenced. Once fully sequenced, the genomes of three CL-N-associated viruses were annotated and the acronym CiLV-N was used to provisionally name them. The genomic information of a fourth isolate collected in MAS was only obtained via RT-PCR using the specific primers for the Sanger-based sequencing of CiLV-N isolates Ibi, SBS, and SRq.

Sequence analysis. Viral ORF were identified in silico using Vector NTI software (Invitrogen, Carlsbad, CA). Nucleotide and deduced amino acid sequences were aligned using CLUSTAL algorithms (Chenna et al. 2003) implemented in the Molecular Evolutionary Genetic Analysis (MEGA) software version 7.0.21 for Windows (Kumar et al. 2016) and in Unipro UGene v1.26.0 (Okonechnikov et al. 2012). Phylogenetic trees were inferred by the maximum-likelihood method using the substitution models with the lowest Bayesian information criterion scores - that is, models LG + G (Le and Gascuel 2008), WAG $+\mathrm{G}+\mathrm{F}$ (Whelan and Goldman 2001), and $\mathrm{LG}+\mathrm{G}+\mathrm{I}+\mathrm{F}$, for the $\mathrm{N}, \mathrm{G}$, and $\mathrm{L}$ protein datasets, respectively. Robustness of the inferred evolutionary relationships was assessed by 1,000 bootstrap replications in MEGA. Presence of genomic repeated-nucleotide sequences were identified using the REPFIND program (https://zlab.bu. edu/repfind/) (Betley et al. 2002), whereas signal peptide, nuclear localization signals (NLS), nuclear export signals (NES), and prediction of transmembrane helices in putative viral proteins were recognized using SignalP 4.1 (Petersen et al. 2011), cNLS Mapper (http://nls-mapper.iab.keio.ac.jp) (Kosugi et al. 2009), NetNES 1.1 Server (http://www.cbs.dtu.dk/services/NetNES/) (la Cour et al. 2004), and TMHMM Server v. 2.0 (http://www.cbs.dtu.dk/services/ TMHMM/), respectively.
RT-PCR tests for the detection of CL-associated viruses. Sequences of $N$ and $L$ genes of CiLV-N isolates were aligned with their cognates from OFV-orchid (GenBank accession numbers AB244417 and AB244418) and OFV-citrus isolates Ja1 (KF198064 and KF198065) and Qto (KF209275 and KF209276), whose sequences were retrieved from the GenBank database. Based on the alignment of the $N$ gene, the primer pair $N$-DC_Br-Fwd ( $5^{\prime}-\mathrm{CCG}$ TACCCATTGTGAAAATA- $\left.3^{\prime}\right)$ and $N$-DC_Br-Rev ( $5^{\prime}$-GAACCCC TTTGAGGAATG-3') was designed with the ultimate goal of detecting exclusively CiLV-N (Fig. 2A). In addition, in an attempt to develop an RT-PCR-based universal detection method for the known CL-causing dichorhaviruses, information obtained from the alignment of the $L$ gene was used to design the pair of degenerate primers $L$-DC-Fwd (5'-CAASTGTCATGCCTGCATGG- $\left.3^{\prime}\right)$ and $L$-DC-Rev (5'-TTGATRCATGATGCRAGRCTGTATG- $3^{\prime}$ ) that target conserved nucleotide sequences (Fig. 2B). Primer performance in PCR was validated using a set of field samples collected in Brazil, Paraguay, and Mexico that showed CL-N symptoms or had tested positive for dichorhavirus infection in TEM analyses.

Mite-mediated virus transmission. In all, 45 adults or nymphs of Brevipalpus spp. mites collected from citrus plants in Ibi showing CL symptoms were transferred to three pots (15 mites per pot) containing 2-week-old $A$. thaliana Col 0 plants. Plants were kept at $23 \pm 1{ }^{\circ} \mathrm{C}$ and with a 14 -h photoperiod inside a controlled growth chamber (Adaptis AR A1000; Conviron, Winnipeg, MB, Canada) throughout the experiment. At 10 to 20 days after infestation, 12 Brevipalpus mites were recovered from the plants and kept in a $70 \%$ ethanol solution until further characterization. Additionally, six pots with healthy sweet orange plants were placed under the leprosis-infected trees to allow a seminatural infection (i.e., leaves and fruit exhibiting CL-N symptoms from the source trees were detached and put in contact with the leaves of the potted trees). After symptoms appeared, leaves from both sweet orange and Arabidopsis were collected and carefully rinsed with sterile distilled water to remove mites, eggs, and other contaminants, and their RNA extracts
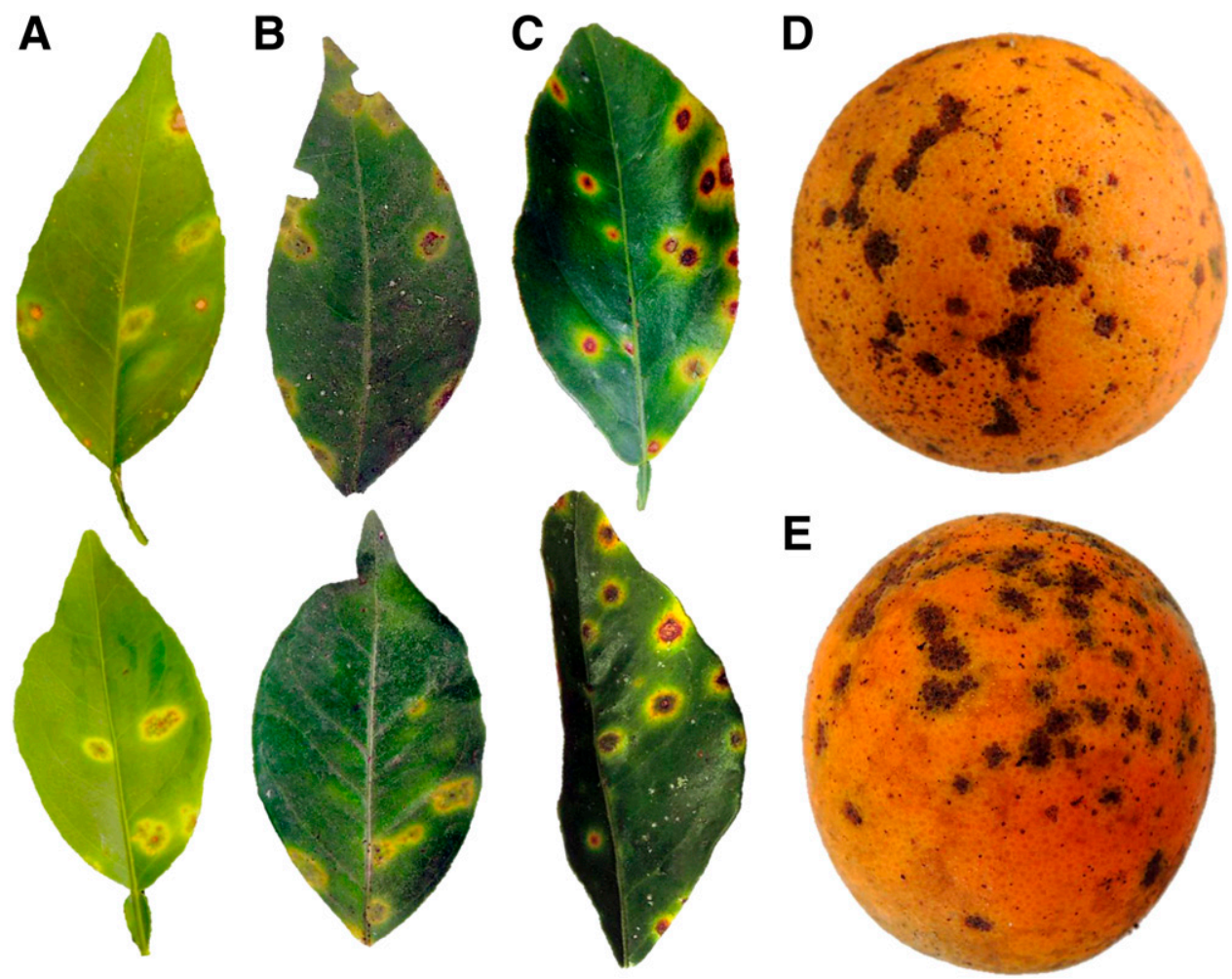

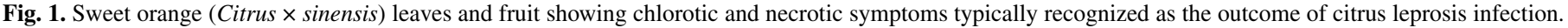
Samples were collected in A, São Bento do Sapucaí; B and D, Ibiúna; and C and E, São Roque counties, State of São Paulo, Brazil in 2015 to 2016. 
were obtained as indicated above. Viral presence in the collected leaves was detected by RT-PCR using the primer pairs $L$-DC and $N$-DC_Br previously described in this work (Fig. 2), and also using the specific primer pair $G$-DC_Br for amplification of a fragment of the $G$ gene of CiLV-N ( $G$-DC_Br-Fwd 5' -CATGGATTTCACAAGGGAAC- ${ }^{\prime}$ ' and $G$-DC_Br-Rev 5'-CACAGATGTTGGCAAAGTAT-3').

Mite identification. Adult Brevipalpus mites collected in Ibi, MAS, and SBS were fixed in $70 \%$ ethanol, mounted for light microscopy in Hoyle's medium, and examined by differential interference contrast in a Zeiss Axioimager microscope (Carl Zeiss AG, Jena, Germany). The images were registered digitally. Additional details were observed under a JEM IT 300 scanning electron microscope (JEOL). For this, mites were dehydrated in ethanol, critical point dried (Leica CPD 300), mounted in double-coated carbon tape on stubs, and sputter coated (Baltec SPD 050; Balzers, Liechtenstein) with gold. Identification of mites was made using morphological criteria recently established for the taxa assignation within the genus Brevipalpus (Beard et al. 2015). A similar protocol was carried out to confirm the identity of mites used in the viral transmission experiments.

\section{RESULTS}

Symptoms, cytopathic effects, and molecular detection tests suggest infections by uncharacterized CL-causing dichorhaviruses. Samples of sweet orange trees suspected to be infected with CL-causing viruses were collected in SBS, Ibi, SRq, and MAS counties in SP, Brazil. Leaves, stems, and fruit showed small, local, necrotic spots. In leaves, they were mostly surrounded by a yellow-bright chlorotic halo (Fig. 1). Remarkably, in some collection sites in the four localities, lime, lemon, and mandarin trees planted next to the symptomatic sweet orange trees remained free of CL symptoms.

TEM analysis of leaf lesions from these symptomatic sweet orange plants revealed the presence of rod-like particles interspersed in the nucleoplasm of the infected cells, suggesting the presence of dichorhaviruses (Fig. 3). In some of these cells, the particles appeared arranged perpendicularly onto the inner nuclear envelope or they formed large parallel and paracrystalline arrays. Rod-like particles were also found in the cytoplasm, and associated perpendicularly onto membranes of the endoplasmic reticulum. Occasionally, this association resulted in a configuration in which particles appear radially arranged and surrounded by endoplasmic reticulum membrane, forming typical "spoke wheel” structures (Kitajima et al. 1972, 2003). Measurements of 50 of these particles revealed that the virions are approximately $40 \mathrm{~nm}$ wide and 100 to $110 \mathrm{~nm}$ long.

RNA extracts from all collected symptomatic trees were tested by RT-PCR using a set of specific primers for the detection of all known CL-causing dichorhaviruses and cileviruses (i.e., CiLV-C, CiLV-C2, and OFV-citrus strains) in addition to OFV-orchid (Locali et al. 2003; Kubo et al. 2009; Ramos-González et al. 2016b; Roy et al. 2013a, 2014). No amplicons were obtained with any of the assayed primer combinations, suggesting that virions detected by TEM differ molecularly from those previously studied.

Genome characterization reveals new CL-associated dichorhaviruses. Total RNA extracts from one infected tree of the localities SBS, SRq, and Ibi were independently sequenced using NGS technology. Reads from each sample were individually assembled to produce a pool of contigs from which those corresponding to the citrus plant genome were separated. In each of the three remaining pools and after BLASTX analyses using a plant virus database as reference, two contigs were identified with relatively low BLAST e-values $\left(<\mathrm{e}^{-80}\right.$ to $\left.\mathrm{e}^{-30}\right)$ with the two genomic fragments of the dichorhaviruses OFV (GenBank accession numbers AB244417 and AB244418) and coffee ringspot virus (CoRSV) (KF812525 and KF812526). Citrus tristeza virus and other virusderived contigs were not detected. Size of overlapping amplicons generated during the Sanger-based secondary sequencing agreed with the expected values according to the organization of the input
A

CiLV-N_Ibi
CiLV-N_SBS
CiLV-N_SRq
CiLV-N_MAS
OFV-orchid
OFV-citrus_Ja-1
OFV-citrus_Qto

B

CiLV-N_Ibi
CiLV-N_SBS
CiLV-N_SRq
CiLV-N_MAS
OFV-orchid
OFV-citrus_Ja-1
OFV-citrus_Qto

N-DC_Brazil_Fwd

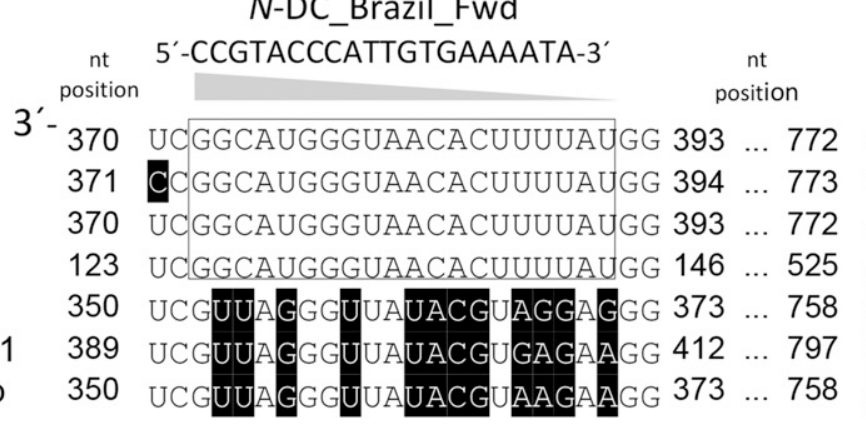

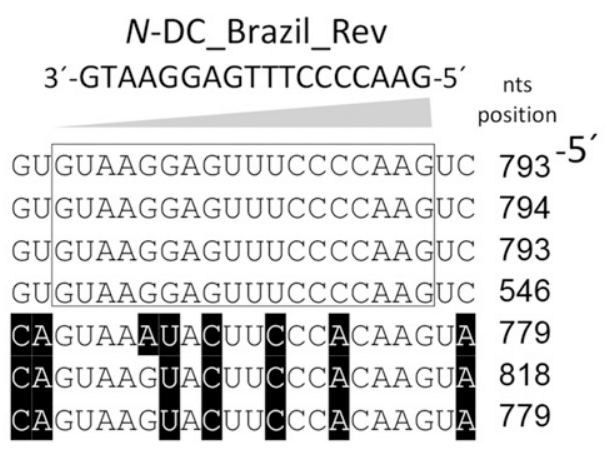

$$
\text { L-DC_Rev }
$$

3'-GTATGTCRGARCGTAGTACRTAGTT-5' nts nt
position

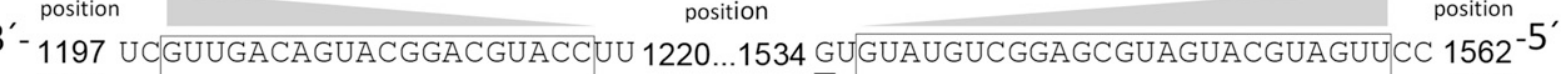
1203 UCGUUGACA GUACGGACGUACCUU 1226...1540 AugUAUGUCGGAGCGUAGUACGUAGUUCC 1568 1200 UCGUUGACA GUACGGACGUACCUU 1223...1537 AUGUAUGUCGGAGCGUAGUACGUAGUUCC 1565 998 UCGUUGACAGUACGGACGUACCUU 1021...1335 AUGUAUGUCGGAGCGUAGUACGUAGUUCC 1363 1180 UCGUUCACAGUACGGACGUACCGU 1197 1180

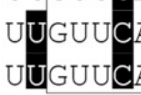

ACAGUACGGACGUACCGU 1203...1517 GUGUAUGUCA GAACGUAGUACAUAGUUUC 1545 1220...1534 GUGUAUGUCGgAACGUAGUACAUAGUUUC 1562 1203...1517 GUGUAUGUCGGAACGUAGUA CAUA GUUUC 1545

Fig. 2. Alignments of partial sequences of the A, RNA1 and B, RNA2 genomic molecules from orchid fleck virus (OFV) and citrus leprosis virus $\mathrm{N}$ (CiLV-N). Bottom line of each panel indicates forward and reverse primer sequences used in virus detection. Target sequences for each primer are highlighted inside open boxes. Primer pair $N$-DC_Brazil is specific for detection of CiLV-N (A) whereas the degenerate primer $L$-DC detects all known citrus leprosis-causing dichorhaviruses (B). $N=N$ gene, $L=L$ gene, and DC = Dichorhavirus-citrus. Nucleotide code: $\mathrm{S}=\mathrm{C}$ or $\mathrm{G}$ and $\mathrm{R}=\mathrm{G}$ or A. Sequences of RNA1 and RNA2 of each virus were retrieved from GenBank. Accession numbers are as follows: CiLV-N_Ibi (KX982176 and KX982179), CiLV-N_SBS (KX982178 and KX982181), CiLVN_SRq (KX982177 and KX982180), CiLV-N_MAS (KY751404 and KY751405), OFV-orchid (AB244417 and AB244418), OFV-citrus_Ja-1 (KF198064 and KF198065), and OFV-citrus_Qto (KF209275 and KF209276). 
scaffolds, proving the correct array of reads and contigs during the assembling processes (data not shown). The full genomes of three different although related viruses were finally obtained after the sequencing of the $3^{\prime}$ and $5^{\prime}$ ends of the two genomic fragments amplified by RACE. It is noteworthy that most of the virus-derived NGS reads corresponded to positive-sense RNA, a fact probably reflecting the enrichment of poly(A) RNA carried out during the RNA library preparation. However, considering that dichorhaviruses,
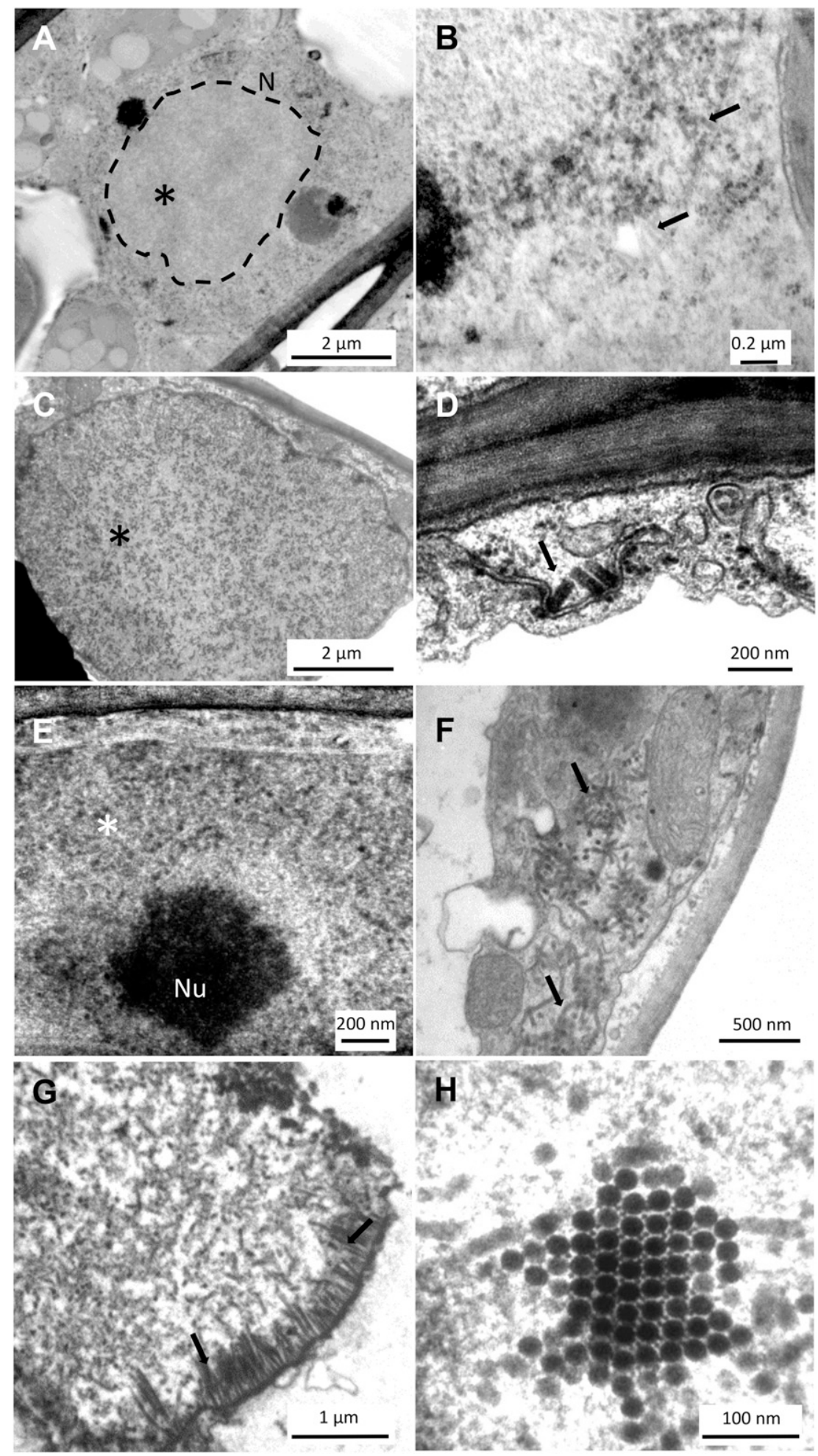

Fig. 3. Transmission electron micrographs of thin sections of leprosis lesions on leaves of sweet orange trees from $\mathbf{A}$ and $\mathbf{B}$, São Bento do Sapucaí; C and $\mathbf{D}$, São Roque; E, Ibiúna; and F, G, and $\mathbf{H}$, Monte Alegre do Sul. A, Low-magnification image showing a large electron lucent viroplasm (*, area inside dashed line) in the nucleus $(\mathrm{N})$ of a palisade parenchyma cell. B, Detail showing some rod-like particles (arrows) in the periphery of the nucleus. C, Nucleus in a spongy parenchyma cell with the viroplasm (*) filled with short rod-like, putative viral particles. D, Cell periphery of a palisade parenchyma cell showing rod-like particles (arrow) attached perpendicularly onto elements of the endoplasmic reticulum. E, Electron lucent viroplasm (*) close to a nucleolus (Nu) in the nucleus of a palisade parenchyma cell. F, Image of a spongy parenchyma cell. Groups of rod-like particles (arrows), presumed virions, are arranged perpendicularly onto membranes of endoplasmic reticulum. G, Nucleus with viroplasm filled with rod-like particles (arrows), which are arranged perpendicularly onto the nuclear membrane of a spongy parenchyma infected cell. H, High-magnification image of a group of rod-like particles in a paracrystalline array, sectioned transversally. A thin fiber-like material is present between adjacent particles. 
like other members of the order Mononegavirales, have negativesense genomes (Afonso et al. 2016; Dietzgen et al. 2014, 2017; Mann and Dietzgen 2014), nucleotide sequences in the $3^{\prime}$ to $5^{\prime}$ orientation were defined as the genome of the identified viruses.

RNA1 of the viruses found in SBS, SRq, and Ibi were 6,708, 6,722 , and 6,724 nucleotides (nt) long, respectively, whereas their RNA2 were $6,051,6,048$, and 6045 nt, respectively. All these sequences were deposited into GenBank and their accession numbers are as follow: isolate Ibi RNA1: KX982176 and RNA2: KX982179, isolate SRq RNA1: KX982177 and RNA2: KX982180, and isolate SBS RNA1: KX982178 and RNA2: KX982181. Between the three RNA1 molecules, those from the isolates SRq and Ibi showed the highest nucleotide identity (97\%), whereas the comparison of each of these molecules with that from the isolate SBS revealed lower values (approximately 92\%). RNA2 of the three isolates were less divergent and, regardless the pair compared, they displayed similar values of sequence identity (97\%) (Supplementary Table S3). By contrast, the genome sequence of the three isolates were notably different from those of OFV and CoRSV. RNA1 and RNA2 showed 52.2 to 53.9 and 59.8 to $62.0 \%$ sequence identity, respectively (Table 1), where the highest values in each range always corresponded to comparisons with CoRSV.

Sanger-based sequencing of amplicons obtained from the isolate collected in MAS allowed the recovery of 93.0 and $94.7 \%$ of its RNA1 (GenBank accession number KY751404) and RNA2 (GenBank accession number KY751405), respectively. The missing sequences were confined to the $3^{\prime}$ and $5^{\prime}$ UTR of both genomic molecules. Nucleotide sequence identities of the sequenced genome and those from the individual ORF with the cognates from the isolates Ibi, SRq, and SBS were always higher than $91 \%$. Highest values in these comparisons were observed with the isolate SBS (data not shown).

In view of the fact that the nucleotide sequence identity between the genomes of the isolates SRq, Ibi, SBS, and MAS are higher than $90 \%$, they were considered to be molecular variants from the same virus. The isolate identified in Ibi was recognized as its prototype, considering that it was found in the region with largest number of $\mathrm{CL}-\mathrm{N}$-infected trees. Moreover, given that this virus seems to be uncharacterized, we named it citrus leprosis virus $\mathrm{N}$, and used the acronym CiLV-N to identify it throughout the article.

By analogy with the OFV genome, the five coding regions in the RNA1 of CiLV-N were annotated as genes $N, P, M P, M$, and $G$ (Fig. 4A). Its RNA2 comprised only one ORF, the largest of the genome, identified as the $L$ gene. Basically, ORF sizes and their relative positions are consistent with those observed in known dichorhaviruses (Cruz-Jaramillo et al. 2014; Dietzgen et al. 2014; Kondo et al. 2006; Ramalho et al. 2014; Roy et al. 2015b) (Supplementary Table S4). In both viral RNA molecules, modular structures encompassed in the gene junctions $(\mathrm{Gj})$ that include the putative gene transcription

TABLE 1. Nucleotide and deduced amino acids identities between citrus leprosis virus $\mathrm{N}(\mathrm{CiLV}-\mathrm{N})$ and known dichorhaviruses

\begin{tabular}{llccc}
\hline & \multicolumn{4}{c}{ Nucleotide identity/amino acid identity $^{\mathrm{a}}$} \\
\cline { 2 - 5 } CiLV-N $^{\mathrm{b}}$ & OFV-orchid & OFV-citrus Qto $^{\mathrm{c}}$ & OFV-citrus Ja1 $^{\mathrm{d}}$ & CoRSV \\
\hline RNA1 & $53.2 /$ nd $^{\mathrm{e}}$ & $52.2 / \mathrm{nd}$ & $52.9 / \mathrm{nd}$ & $53.9 / \mathrm{nd}$ \\
ORF $N$ & $56.8 / 50.7$ & $57.3 / 50.0$ & $57.4 / 50.2$ & $60.2 / 57.9$ \\
ORF $P$ & $52.2 / 36.2$ & $51.6 / 35.8$ & $52.7 / 36.6$ & $55.3 / 46.9$ \\
ORF MP & $64.0 / 61.0$ & $57.8 / 54.7$ & $58.3 / 55.0$ & $63.4 / 58.6$ \\
ORF $M$ & $49.2 / 36.8$ & $51.6 / 36.3$ & $51.9 / 36.8$ & $57.0 / 49.7$ \\
ORF $G$ & $48.6 / 33.9$ & $49.7 / 32.7$ & $49.4 / 33.4$ & $50.5 / 39.0$ \\
RNA2 & $60.4 /$ nd & $59.8 / \mathrm{nd}$ & $60.5 / \mathrm{nd}$ & $62.0 / \mathrm{nd}$ \\
ORF $L$ & $61.2 / 57.5$ & $61.6 / 57.6$ & $61.7 / 57.2$ & $62.8 / 63.8$ \\
\hline
\end{tabular}

a $\mathrm{OFV}=$ orchid fleck virus and CoRSV $=$ coffee ringspot virus.

b Sequences from isolate Ibi were selected for the comparisons (GenBank accession numbers RNA1 $=$ KX982176 and RNA2 $=$ KX982179). ORF $=$ open reading frame.

c Isolate from Queretaro, Mexico.

d Isolate from Jalisco, Mexico.

e nd = data not determined. start site, the IG region, and the polyadenylation signal ( $3^{\prime}$-UAA AUUU-5') were identified (Fig. 4B). Throughout the genome of CiLV-N isolates, the IG regions were regularly formed by the tetranucleotide GXXX and, next to this, there was always a dinucleotide UU which, by analogy with OFV-orchid (Kondo et al. 2014), might represent the transcriptional start site for the upcoming gene. The classic modular organization of the IG region could not be recognized in either $\mathrm{Gj}_{1}$ (leader/ORF1) or $\mathrm{Gj}_{6}$ (ORF5/trailer) of the RNA1, as well as in $\mathrm{Gj}_{7}$ (leader/ORF6) or $\mathrm{Gj}_{8}$ (ORF6/trailer) of the RNA2. In $\mathrm{Gj}_{1}$ and $\mathrm{Gj}_{7}$, although U-rich regions were detected, they differed from the canonical polyadenylation signal sequence. Thus, if any short transcripts are expressed from the leader regions of the genomic RNA of CiLV-N, or whether or not they are polyadenylated, cannot be inferred in silico.

Genome analysis of CiLV-N isolates also revealed that the interORF regions harboring the $\mathrm{Gj}_{3}, \mathrm{Gj}_{4}$, and $\mathrm{Gj}_{5}$ are two or three times larger than those observed in OFV, being closer in length to the cognates from CoRSV (less than 20\% size difference). Lengths of $3^{\prime}$ UTR (approximately $247 \mathrm{nt}$ ) and 5' UTR (approximately $200 \mathrm{nt}$ ) flanking the RNA1 and their A + U contents (55.5 to 59.5\%) were similar to those exhibited by OFV. In the RNA2, these sequence stretches also had lengths similar to those in OFV (less than $12 \%$ size difference) but the A + U content of its 5' UTR was slightly higher (64.6 to $65.5 \%$ in CiLV-N versus $56.2 \%$ in OFV). In this regard, the presence of leader RNA in both genome molecules of CiLV-N makes a marked contrast with OFV-citrus isolate Qto, in which these sequences are lacking (Roy et al. 2015b).

Deduced amino acid sequences of protein encoded by each ORF detected in the genomes of each isolate of CiLV-N showed high values of identity between them ( $\geq 96 \%)$. However, in the evaluations including proteins from OFV and CoRSV, the values were notably reduced (Table 1). Overall, the percentage of identity in these analyses ranged from the lowest values (32.7 to 39\%), corresponding to the $\mathrm{G}$ protein, to the highest in comparisons involving the $\mathrm{N}(50.0$ to $57.9 \%)$, MP (54.7 to $61.0 \%$ ), and L (57.2 to $63.8 \%$ ) proteins. Detailed analyses of these proteins using several bioinformatics tools predicted the presence of NLS, NES, signal peptides, and transmembrane regions, which might be relevant for their functions during the infection cycle according to studies with OFV and CoRSV (Kondo et al. 2013; Ramalho et al. 2014). NES were identified in the nucleocapsid protein (peptides AAITYICLSLLRLCV, amino acid positions 151 to 171; and IPYGMYIDLKMGLPL, amino acid positions 261 to 275), phosphoprotein (SWLLIDYLS, amino acid positions 169 to 177), and matrix protein (SLSLIN, amino acid positions 43 to 48). The phosphoprotein also has two NLS predicted between amino acid positions 125 to 134 and 226 to 236 (peptides QSSKRKHEDT and RLSKSKKPCLN, respectively). The G protein has a predicted signal peptide whose cleavage site is between the residues Gly 21 and Met22 and a putative transmembrane helix domain near its $C$ terminus (amino acid positions 483 to 502). The $\mathrm{L}$ protein from CiLV-N shows large stretches of conserved amino acid sequences, including the characteristic four motifs identified inside the domain III of RNA-dependent RNA polymerase of dichorhaviruses (Ramalho et al. 2014; Roy et al. 2015b) and mononegaviruses (Poch et al. 1990). The sequence of the motif D of the L protein was the less conserved (data not shown), as also was described for other dichorhaviruses (Ramalho et al. 2014; Roy et al. 2015b).

Phylogenetic analyses using the deduced amino acid sequences of the N, G, and L proteins from several plant-infecting rhabdoviruses revealed trees with similar topology (Fig. 5). Clusters corresponding to genera Cytorhabdovirus, Nucleorhabdovirus, Varicosavirus, and Dichorhavirus were well defined although, in the L protein-based tree, the branch including dichorhaviruses arose from the same node where the nucleorhabdoviruses maize fine streak virus, datura yellow vein virus, and sonchus yellow net virus probably descended, denoting their putative closer ancestrally. Inside the branch corresponding to the genus Dichorhavirus, the members were always subclustered in such 
a way that the OFV isolates from both orchid and citrus were clearly separated from CoRSV and from the isolates of CiLV-N.

Specific and generic detection of dichorhaviruses infecting citrus. The performance of the primer pairs $N$-DC_Br and $L$-DC designed in this work (Fig. 2) were tested using cDNA extracts obtained from $12 \mathrm{CL}-\mathrm{N}$-infected citrus plants collected in Brazil and Mexico, and from orchid plants infected with OFV collected in Brazil and Paraguay. As would be expected according to the in silico analyses, using the specific $N$-DC_Br primers, amplicons of approximately 420 bp were observed only in samples of CiLV-N, which were collected in Ibi, SRq, SBS, MAS, Amparo, and Serra Negra (Fig. 6A). PCR with primers $L$-DC, designed to amplify the $L$ gene of all CLassociated dichorhaviruses, resulted in amplification from a wider range of samples (Fig. 6B). In addition of those corresponding to isolates of CiLV-N, bands of approximately $360 \mathrm{bp}$ were obtained from the cDNA extracts of orchid collected in Piracicaba, SP, Brazil and Asunción, Paraguay and in citrus plants collected in Atotonilco and Ameca, State of Jalisco, Mexico, where the presence of OFV was previously detected (Ramos-González et al. 2016b). Ampliconderived sequences of samples from Ibi, SRq, SBS, and MAS showed $>99 \%$ identity with the cognate reference genome which allowed the validation of the effectiveness of the designed primers. In the case of samples from Amparo (GenBank accession numbers KY711427 and KY711429) and Serra Negra (GenBank accession numbers KY711428 and KY711430), the sequences exhibited $>93 \%$ identity with the genome of CiLV-N isolate Ibi.

Mite-mediated transmission of CiLV-N to Arabidopsis and sweet orange plants. At 8 to 10 days after infestation with Brevipalpus mites collected in Ibi, symptoms of local chlorotic lesions were evident in some leaves of the inoculated Arabidopsis plants (Fig. 7A). Symptoms of CL-N in the sweet orange plants left under the canopy of the CL-N source plants were observed after 3 months. However, in the case of sweet orange plants, this time should not be judged as the minimal period required for symptom appearance; it only represents the interval between the first (beginning of the experiment) and second visits to the experimental area.

Presence of CiLV-N in the RNA extracts from symptomatic leaves from the infested plants of the two species was confirmed by using $N$-DC_Br, $L$-DC, and $G$-DC_Br primer pairs (Figs. 6, lanes 17 to 19 , and $7 \mathrm{~B}$ ). Nucleotide sequences of the amplicons (GenBank accession numbers KY711421-22 and KY711425-26) showed $>95 \%$ identity with the sequence of CiLV-N isolate Ibi.

Mite characterization. In total, 65 mites collected in citrus trees showing CL-N symptoms (that also proved positive for CiLV-N) from Ibi (50 specimens), MAS (12 specimens), and SBS (3 specimens) were evaluated according to the current taxonomical criteria for members of the genus Brevipalpus (Beard et al. 2015)

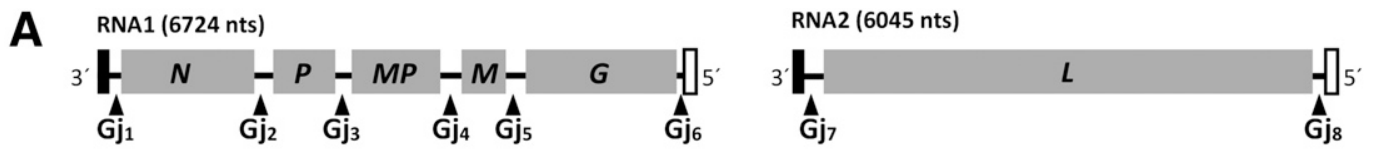

B

Gene junction structure

\begin{tabular}{|c|c|c|c|c|c|c|}
\hline & & \multirow{2}{*}{$\begin{array}{c}3^{\prime}- \\
n t \\
\text { position }\end{array}$} & Polyadenylation signal & IG & Transcription start site & \multirow{2}{*}{$\begin{array}{l}-5^{\prime} \\
{ }^{n t} \\
\text { position }\end{array}$} \\
\hline & & & & & & \\
\hline & SBS & 163 & \multirow{3}{*}{-} & \multirow{3}{*}{-} & \multirow{3}{*}{ UUACU } & 172 \\
\hline \multirow[t]{3}{*}{$\mathrm{Gj}_{1}$} & SRq & 162 & & & & 171 \\
\hline & $\mathrm{Ibi}$ & 162 & & & & 171 \\
\hline & SBS & 1662 & \multirow{3}{*}{ UAAAUUUAUUUU } & GUAG & UUAUU & 1682 \\
\hline \multirow[t]{2}{*}{$\mathrm{Gj}_{2}$} & SRq & 1659 & & GGAG & \multirow{2}{*}{ UUACU } & 1678 \\
\hline & Ibi & 1659 & & GUAG & & 1678 \\
\hline \multirow{3}{*}{$\mathrm{Gj}_{3}$} & SBS & 2683 & \multirow{3}{*}{ UAAAUUUAUUUU } & \multirow{3}{*}{ GUAG } & \multirow{3}{*}{ UUACG } & 2702 \\
\hline & SRq & 2682 & & & & 2701 \\
\hline & Ibi & 2682 & & & & 2701 \\
\hline \multirow{3}{*}{$\mathrm{Gj}_{4}$} & SBS & 3941 & \multirow{3}{*}{ UAAAUUUAUUUU } & GUGG & \multirow{3}{*}{ UUGUU } & 3961 \\
\hline & SRq & 3942 & & & & 3962 \\
\hline & $\mathrm{Ibi}$ & 3942 & & GUAG & & 3964 \\
\hline \multirow{3}{*}{$\mathrm{Gj}_{5}$} & SBS & 4843 & \multirow{3}{*}{ UAAAUUUAUUUU } & \multirow{3}{*}{ GUUG } & UUGUG & 4863 \\
\hline & SRq & 4841 & & & \multirow{2}{*}{ UUGUA } & 4861 \\
\hline & $\mathrm{Ibi}$ & 4843 & & & & 4863 \\
\hline \multirow{3}{*}{$\mathrm{Gj}_{6}$} & SBS & 6551 & \multirow{3}{*}{ UAAAUUUGUUUU } & GUCC & \multirow{3}{*}{-} & 6566 \\
\hline & SRq & 6564 & & GGUC & & 6579 \\
\hline & Ibi & 6566 & & GGUC & & 6581 \\
\hline \multirow{3}{*}{$\mathrm{Gj}_{7}$} & SBS & 179 & \multirow{3}{*}{-} & \multirow{3}{*}{-} & \multirow{2}{*}{ UUGAG } & 187 \\
\hline & SRq & 176 & & & & 184 \\
\hline & $\mathrm{Ibi}$ & 173 & & & UUUUG & 181 \\
\hline \multirow{3}{*}{$\mathrm{Gj}_{8}$} & SBS & 5863 & \multirow{3}{*}{ UAAAUUUGUUUU } & \multirow{3}{*}{ GAUU } & \multirow{3}{*}{-} & 5878 \\
\hline & SRq & 5860 & & & & 5875 \\
\hline & $\mathrm{Ibi}$ & 5857 & & & & 5872 \\
\hline
\end{tabular}

Fig. 4. A, Genomic organization of citrus leprosis virus $N(\mathrm{CiLV}-\mathrm{N})$ isolate Ibiúna. Gray boxes indicate the six viral open reading frames encoded by the bipartite genome. $N=N$ gene, nucleocapsid protein; $P=P$ gene, phosphoprotein; $M P=M P$ gene, movement protein, $M=M$ gene, matrix protein; $G=G$ gene, glycoprotein; and $L=L$ gene, RNA-dependent RNA polymerase. Solid black and open boxes designate the leader and trailer sequences on the $3^{\prime}$ and $5^{\prime}$ ends, respectively, of each RNA molecule. Arrowheads show gene junction $(\mathrm{Gj})$ distribution in the genome. B, Structures and sequences of Gj of the isolates São Bento do Sapucaí (SBS), São Roque (SRq), and Ibiúna (Ibi) are depicted. Nonconserved nucleotides are highlighted in bold. IG = intergenic region. 
(Fig. 8). All the specimens were identified as B. phoenicis sensu stricto. The following traits were observed: (i) central cuticle with strong broad areolae in the prodorsum; (ii) in the dorsal opisthosoma, dl-dl to $e l-e l$, cuticle with a few transverse folds and sublateral cuticle exhibiting rounded cells in bands; (iii) cuticle of the ventral plate forming transverse bands; (iv) genital plate with large cells; (v) spermathecal apparatus ending in a bulb; and (vi) palp femorogenu dorsal seta flat, barbed, and broad. Moreover, cuticular microplates
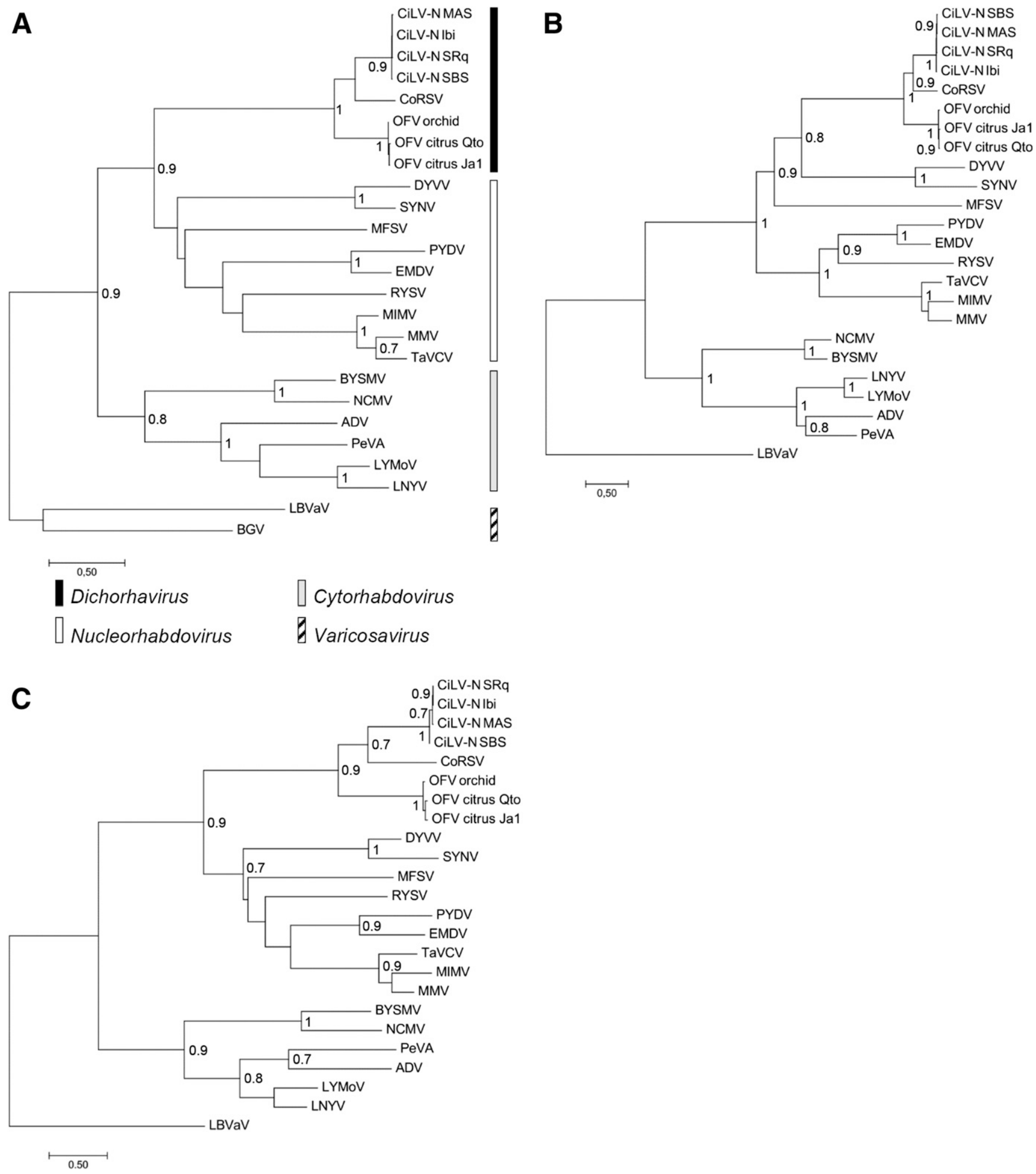

Fig. 5. Phylogenetic reconstruction for plant-infecting viruses of the family Rhabdoviridae. Maximum-likelihood-inferred trees include members of the genera Dichorhavirus, Cytorhabdovirus, Nucleorhabdovirus, and Varicosavirus, and they are based on the amino acid sequences of A, N proteins; B, L proteins; and C, G proteins. Bootstrap support values (1,000 iterations) of branches are indicated near to the nodes if greater than 70\%. Lettuce big vein associated virus (LBVaV)derived sequences were used as outgroup. CiLV-N $=$ citrus leprosis virus $\mathrm{N}, \mathrm{CoRSV}=$ coffee ringspot virus, $\mathrm{OFV}=$ orchid fleck virus, DYVV $=$ datura yellow vein virus, SYNV = sonchus yellow net virus, MFSV = maize fine streak virus, PYDV = potato yellow dwarf virus, EMDV = eggplant mottled dwarf virus, RYSV $=$ rice yellow stunt virus, MIMV = maize Iranian mosaic virus, MMV = maize mosaic virus, TaVCV $=$ taro vein chlorosis virus, BYSMV = barley yellow striate mosaic virus, $\mathrm{NCMV}=$ northern cereal mosaic virus, $\mathrm{ADV}=$ alfalfa dwarf virus, $\mathrm{PeVA}=$ persimmon virus $\mathrm{A}, \mathrm{LNYV}=$ lettuce necrotic yellows virus, $\mathrm{BGV}=\mathrm{black}$ grass varicosavirus-like virus (GenBank accession number NC026801), and $\mathrm{LYMoV}=$ lettuce yellow mottle virus. 
over the dorsal surface of these mites showed irregular multidirectional ridges (Fig. 8C).

Mites that transitorily fed on Arabidopsis plants during the transmission experiments of CiLV-N were anatomized as well. All

\section{A Specific detection of $\boldsymbol{N}$ gene of CiLV-N}

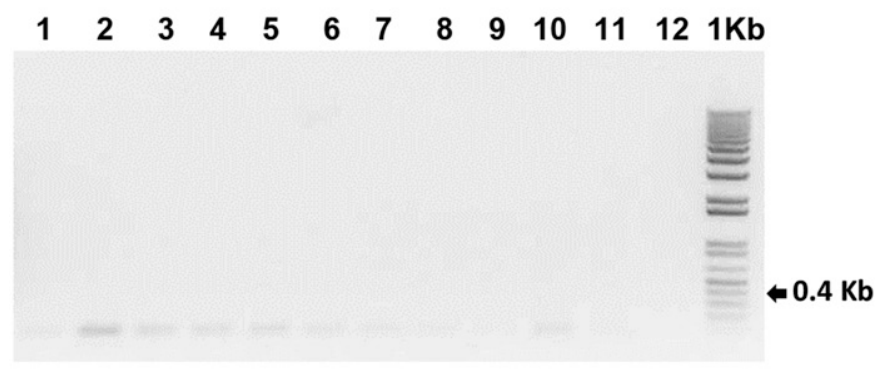

$\begin{array}{lllllllllllll}13 & 14 & 15 & 16 & 17 & 18 & 19 & 20 & 21 & 22 & 23 & 24 & 1 K b\end{array}$
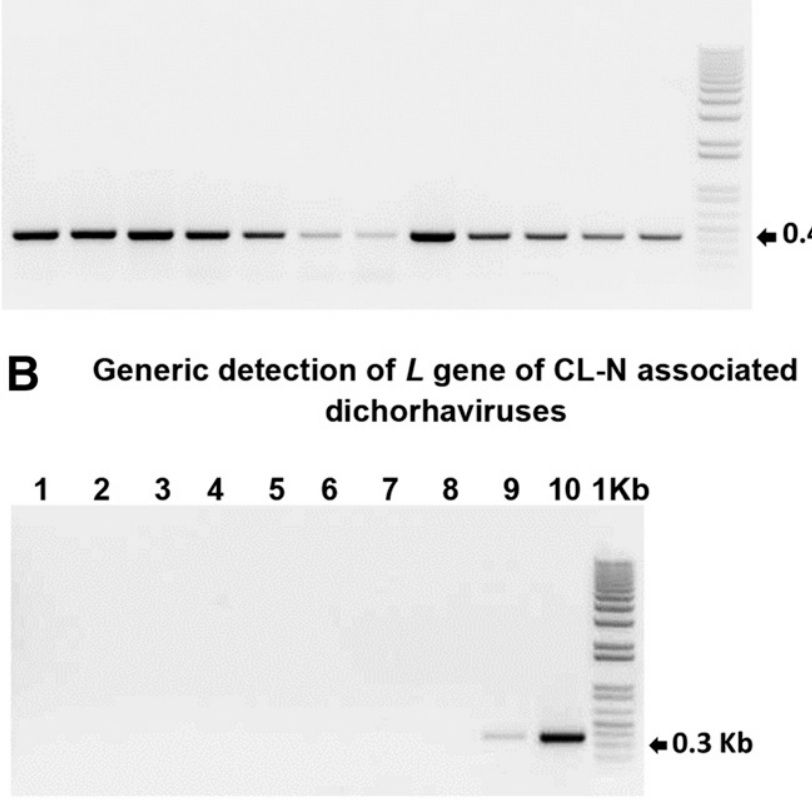

$\begin{array}{lllllllllll}11 & 12 & 13 & 15 & 16 & 17 & 18 & 19 & 22 & 24 & 1 \mathrm{~Kb}\end{array}$

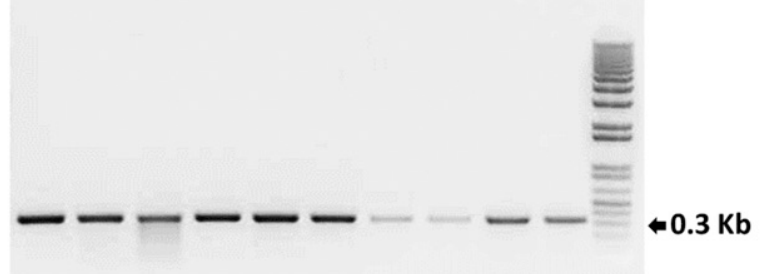

Fig. 6. Gel electrophoresis of reverse-transcription polymerase chain reaction (RT-PCR) products for $\mathbf{A}$, specific detection of citrus leprosis virus N (CiLV$\mathrm{N}$ ) using the primer pair $N$-DC_Br (expected amplicon size: $420 \mathrm{bp}$ ) and $\mathbf{B}$, generic detection of citrus leprosis-nuclear (CL-N)-associated dichorhaviruses using the primer pair $L$-DC (expected amplicon size: $360 \mathrm{bp}$ ). Lane 1: notemplate PCR control, lane 2: no-template RT control, lane 3: healthy citrus plant, lane 4: healthy orchid plant, lane 5: healthy Arabidopsis plant, lane 6: CiLV-Cinfected citrus plant (Cordeirópolis, Brazil), lane 7: CiLV-C2-infected citrus plant (Meta, Colombia), lane 8: coffee ringspot virus-infected coffee plant (Limeira, Brazil), lanes 9 and 10: orchid fleck virus (OFV)-infected orchid plants (Piracicaba, Brazil and Asunción, Paraguay, respectively), lanes 11 and 12: OFV-citrus infected plants (Atotonilco and Ameca, Mexico, respectively), lanes 13 to 17 and 20 to 24: CiLV-N-infected sweet orange plants (Ibiúna, São Roque, Monte Alegre do Sul, Amparo, and Serra Negra, Brazil), lanes 18 to 19: CiLV-N-infected Arabidopsis plants (inoculated with Brevipalpus phoenicis sensu stricto collected in Ibiúna), and $1 \mathrm{~Kb}$ : molecular weight marker 1-kb Plus DNA Ladder (Thermo Fisher Scientific, Waltham, MA). structural details observed in the field-collected specimens were also discerned across the specimens of the subpopulation.

\section{DISCUSSION}

In this work, we provide biological and molecular evidence to support the conclusion that the causal agent of CL-N in Brazil, which we propose to call citrus leprosis virus $\mathrm{N}(\mathrm{CiLV}-\mathrm{N})$, is different from those characterized elsewhere. CL symptoms were described in the Americas in the early 1900s but only in the 1970s did Kitajima and collaborators associate the conspicuous symptoms with the presence of either one of the two types of short-bacilliform or rod-like particles observed in TEM (Kitajima et al. 1972, 1974b) and later considered "cytoplasmic and nuclear types" of citrus leprosis virus (Rodrigues et al. 2003).

In 2012, the species Citrus leprosis virus $C$ was accepted by the International Committee on Taxonomy of Viruses (ICTV) to classify the prevalent virus that cause CL-C, and it was defined as the type member of genus Cilevirus (Locali-Fabris et al. 2012). CL-N is of rare occurrence and, in contrast to $\mathrm{CL}-\mathrm{C}$, it has not received much attention over the years and its possible economic losses were not yet assessed (Bastianel et al. 2010). Its causal agent has been generally called citrus leprosis virus nuclear type (Rodrigues et al. 2003), which
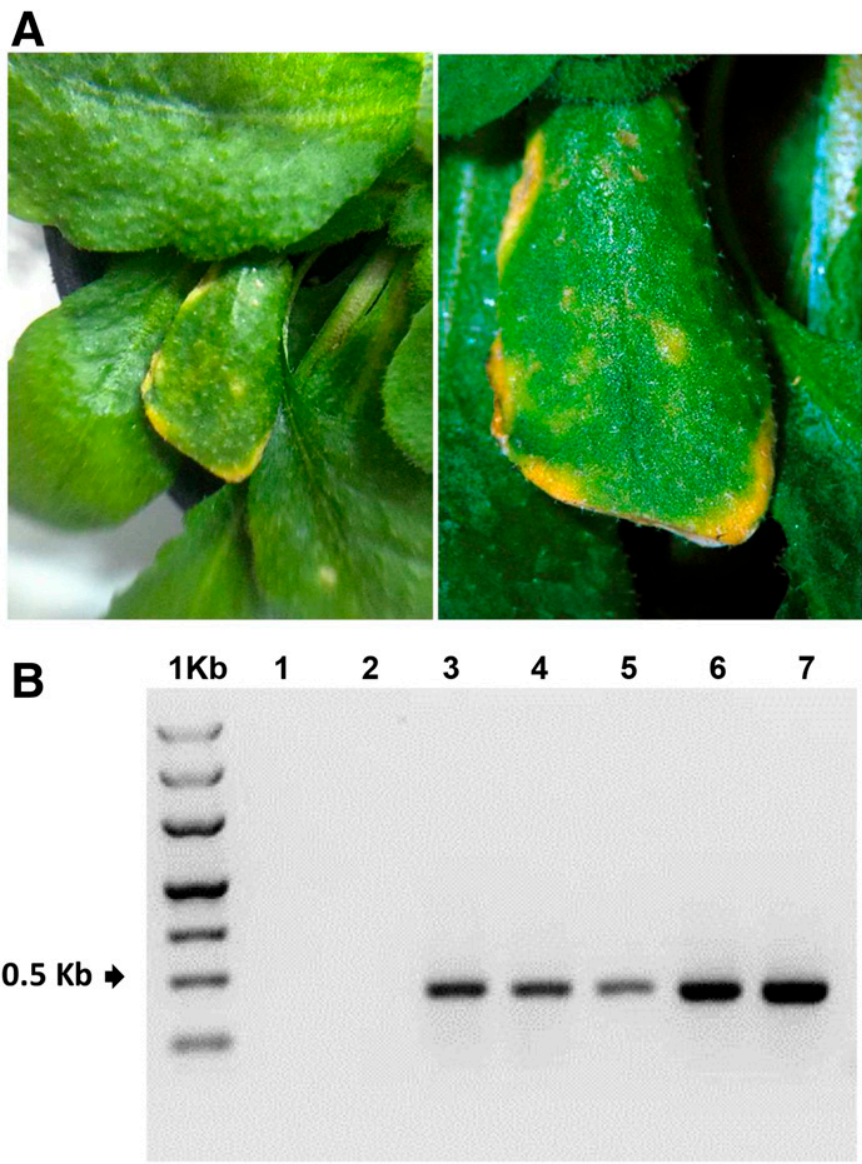

Fig. 7. Transmission of citrus leprosis virus N (CiLV-N) to Arabidopsis thaliana using viruliferous Brevipalpus phoenicis sensu stricto mites collected in Ibiúna, SP, Brazil. A, Chlorotic symptoms in Arabidopsis leaves after 8 to 10 days of infestation with viruliferous mites. B, Agarose gel (1\%) electrophoresis of reverse-transcription polymerase chain reaction (RT-PCR) products for the detection of CiLV-N using a specific primer pair for the $N$ gene $(N$-DC_Br $)$. Expected amplicon size $=420$ bp. $1 \mathrm{~Kb}$ : Molecular weight marker M1121 (Sinapse Biotecnologia, SP, Brazil), lane 1: no-template RT-PCR control, lane 2: healthy Arabidopsis plant, lanes 3 to 5: symptomatic leaves from three different Arabidopsis-infested plants, and lane 6: sweet orange (Citrus $\times$ sinensis) tree infected with CiLV-N isolate Ibi. 
seemed appropriate until recently, when the diversity of CL-Nassociated viruses began to be unraveled. Two research groups reported the complete genome sequences of viruses causing CL-N in Mexico and named them Citrus leprosis virus nuclear type and Citrus necrotic spot virus (Cruz-Jaramillo et al. 2014; Roy et al. 2013b). Shortly after that, it was decided by the ICTV Mononegavirales Study Group and collaborators that, in fact, both viruses are citrus strains of
OFV, because they share more than $90 \%$ nucleotide sequence identity (Afonso et al. 2016). Hence, for the sake of clarity and unambiguity, the designations citrus leprosis virus nuclear type and citrus necrotic spot virus should not be used any longer to designate those viruses, which should instead be referred to as citrus strains of OFV.

Yet another CL-N virus was recently characterized. Hartung et al. (2015) obtained a herbarium sample collected in Volusia County,
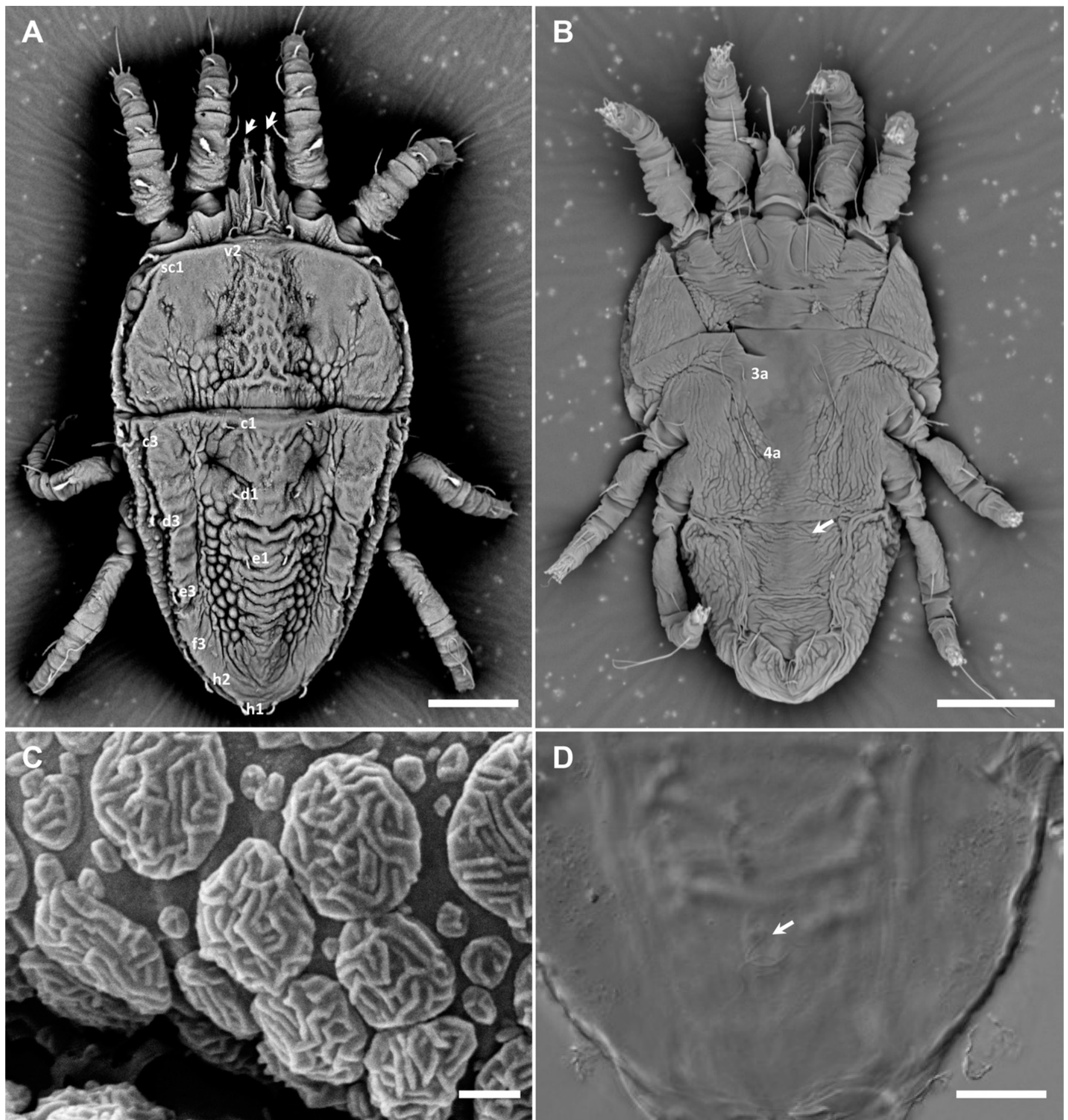

Fig. 8. Microphotographs of Brevipalpus phoenicis sensu stricto mites collected in sweet orange (Citrus $\times$ sinensis) trees showing citrus leprosis-nuclear (CL-N) symptoms (individuals from Ibiúna, SP, Brazil). Morphological characteristics are depicted in four panels. A, Dorsal view. Cuticle of the propodosoma, sc1 = scapular seta and v2 = vertical seta, presence of strong, broad areolae on the median area of prodorsum. White arrows show palp femorogenu with dorsal seta broad, flat, and barbed; dorsal cuticle of the opisthosoma strongly reticulate, setae $=c 1, c 3, d 1, d 3, e 1, e 3, f 3, h 1, h 2 ; e 1-e 1$ to $h 1-h 1$ cuticle with transverse folds, sublateral cuticle with a band of large distinctly round cells. B, Ventral view of the cuticle between aggential setae $3 \mathrm{a}$ and $4 \mathrm{a}$. White arrow shows the ventral and genital shield with fused transverse bands. C, Microplates. D, White arrow shows spermatheca, a thick duct terminating in a bulb. Calibration bars: A and B = $50 \mu \mathrm{m}, \mathrm{C}=0.5 \mu \mathrm{m}$, and $\mathrm{D}=20 \mu \mathrm{m}$. 
FL, in 1948 and were able to partially sequence and assemble the viral genome. The authors not only confirmed the hypothesis formulated by Kitajima et al. (2011), who suggested that the Floridian causal agent of leprosis might have been of the nuclear type, but also showed that it was probably a different dichorhavirus, sharing approximately $80 \%$ nucleotide sequence identity with the OFVcitrus strain from Mexico (Hartung et al. 2015). However, the genome sequence obtained corresponds to only approximately $61 \%$ of the two RNA and the virus does not occur in nature any longer, which makes it impossible to determine unequivocally whether it indeed belongs to a different virus species.

The first confirmed report of a CL-N-associated virus in citrus was from SP, Brazil, when Kitajima et al. (1972) detected the presence of short rod-like particles in sweet orange and grapefruit plants through TEM analyses. Later, similar analyses revealed the occurrence of CL-N in at least six municipalities in SP, as well as in two other Brazilian states (Rio Grande do Sul and Minas Gerais) (Bastianel et al. 2010). A pattern could be observed in all of these cases: CL-N occurred in sweet orange plants grown in residential backyards at higher altitudes and under cooler weather conditions (Bastianel et al. 2010).

Based on recent data on citrus-infecting dichorhaviruses, and considering that the CL-N causal agent in Brazil could not be detected by primers that specifically detect strains of OFV (from either orchid or citrus) by RT-PCR, a thorough biological and molecular characterization of the Brazilian CL-N pathogen was performed. Taken together, the following features placed it within the dichorhavirids: (i) induction of typical localized chlorotic or necrotic leprosis-like symptoms in sweet orange plants; (ii) presence of short rod-like virions of approximately 40 to $100 \mathrm{~nm}$ in length, spoke-wheel structure, or electron-lucent viroplasms in infected cells analyzed by TEM; (iii) Brevipalpus mite transmission to both sweet orange and A. thaliana plants yielding localized lesions in the latter, which was recently shown to be a good experimental host for at least two other dichorhaviruses (CoRSV and the tentative dichorhavirids Clerodendrum chlorotic spot virus [ClCSV]) (Arena et al. 2017); and (iv) genome size and organization similar to that of dichorhaviruses. This newly sequenced virus has a bipartite (-) ssRNA genome of approximately 6.7 and $6.0 \mathrm{~kb}$ for each molecule, of which the RNA1 encodes five ORF, equivalent to genes $N, P, M P, M$, and $G$ of rhabdovirids, whereas the RNA2 accommodates a single $\mathrm{ORF}$, corresponding to the $L$ gene. Moreover, all genes are separated by $\mathrm{Gj}$, which include the putative gene transcription start site, the conserved IG region, and the polyadenylation signal (Dietzgen et al. 2017).

Of particular interest was the observation that, for RNA1, the lengths of some the Gj of CiLV-N were much more similar to those of CoRSV than those of OFV. Variability of inter-ORF regions and, in general, of the genomes throughout viruses of the family Rhabdoviridae was previously reported (Walker et al. 2015). This extensive study on the evolution of 99 animal rhabdoviruses showed that lengths of $\mathrm{Gj}$ are extremely variable within the family, being responsible for up to $48.5 \%$ of the variation in genome size from the smallest to the largest evaluated genomes (Walker et al. 2015). It is believed that the plasticity of the genome length of these viruses is a reflection of the discontinuous transcription strategy used for the expression of their genes and might be used to reveal phylogenetic relationships among rhabdoviruses (Walker et al. 2015). However, and similar to other RNA viruses, their monopartite genome sizes should be restricted due to high error rates leading to deleterious mutations (Holmes 2003; Walker et al. 2015). The question of whether or not rhabdoviruses with a bipartite genome such as those from the genus Dichorhavirus arose from the need, at least partially, to overcome such size limitations needs to be addressed.

Altogether, our data do not leave doubts regarding the assignment of CiLV-N within the dichorhavirids. Moreover, they support the idea that the four sequenced isolates might be assigned to a new species of Dichorhavirus. According to the proposal of Dietzgen et al. (2014), accepted by the ICTV (Walker et al. 2014), species demarcation within the genus Dichorhavirus includes differences of $>25 \%$ in the $L$ gene nucleotide sequence and $>10 \%$ in the complete genome sequence identity. CiLV-N RNA1 and RNA2 share less than $62 \%$ identity with the two definitive members of the genus, OFV and CoRSV (Table 1). Moreover, identities between the $L$ gene of CiLV-N and those of OFV and CoRSV reach 61.2 and $62.8 \%$, respectively (Table 1 ), falling below the $75 \%$ threshold of species demarcation.

As expected for such low identity values between CiLV-N and known dichorhaviruses, the primers used for the amplification of OFV, including the citrus strain of the virus, cannot detect CiLV-N. Hence, we designed a primer pair that specifically amplifies CiLV-N and can be used to differentiate it from other CL-N-causing viruses (Fig. 6A). In addition, we also designed primers for the $L$ gene that are able to detect both circulating CL-N viruses (i.e., OFV and CiLV-N). These primers were validated and can be useful for surveys and further characterization of these and perhaps other CL-associated dichorhaviruses (Fig. 6B).

Phylogenetic analyses reveal that the CiLV-N isolates are more closely related to CoRSV than to OFV (Fig. 5). Coincidently or not, reports of both $\mathrm{CL}$ and coffee ringspot diseases in Brazil date from 1930s (Bitancourt 1938, 1940), whereas orchid fleck was first reported decades later in Japan (Doi et al. 1969) and Brazil (Kitajima et al. 1974a). Obviously, which of the CL-C- and CL-N-associated viruses were present in Brazil more than 80 years ago may never be known. However, it is reasonable to speculate that CiLV-N has been associated with the recurrently reported cases of CL-N in Brazil and, accordingly, this virus may be the first described among the citrusassociated dichorhaviruses that are currently circulating in the field.

Although the biological characterization may not be always essential for species demarcation within a particular genus (Dietzgen et al. 2014; Simmonds et al. 2017), we consider that, for CiLV-N, it clearly strengthens the proposal for creating a new species within genus Dichorhavirus due to several distinct features it presents when compared with other members of the genus. Moreover, some of the biological features observed may have an impact on the epidemiology of the disease and help explain the distribution of such pathogens in citrus orchards.

Brevipalpus specimens collected in symptomatic orange trees from Ibi, SBS, and MAS were all identified as B. phoenicis sensu stricto based on the taxonomic features proposed by Beard et al. (2015). Experimental transmission of CiLV-N using viruliferous $B$. phoenicis sensu stricto to A. thaliana was achieved. Our results also indicated that $B$. phoenicis sensu stricto mediated the transmission of this virus to healthy sweet orange plants in seminatural conditions. Viral detection in the infested plants using specific primers and the high identity of the amplicon sequences with those from the virus genome confirmed the capacity of B. phoenicis sensu stricto as a dichorhavirus vector. In agreement with these findings, rod-like particles similar to those observed in CiLV-N-infected plants were found in previous TEM analyses of Brevipalpus mites collected from the same infected sweet orange trees in MAS (Kitajima and Alberti 2014). As described for other nuclear-type Brevipalpustransmitted viruses (Dietzgen et al. 2014), in those samples, the authors observed not only virions but also the presence of viroplasm in the nucleus of infected mite cells, suggesting the replication of the virus in its vector. Hence, the relationship between CiLV-N and B. phoenicis sensu stricto, as well as other dichorhaviruses and their Brevipalpus vectors, appears to be of the persistent-replicative type (Kitajima and Alberti 2014).

CL-N diseases from Florida, Mexico, and Colombia have been associated with B. californicus, the known vector of OFV (Kondo et al. 2003; Roy et al. 2015a). B. californicus colonizes citrus in several countries of the Americas (Childers et al. 2003b; Knorr 1968; Roy et al. 2015a; Salinas-Vargas et al. 2013, 2016) but, in Brazil, this mite species is rarely found in citrus orchards. The only existing report found in our search indicates an incidence of $B$. californicus at less than $0.1 \%$ of the total phytophagous mites surveyed in sweet 
orange trees in the state of Amazonas (Bobot et al. 2011). Apparently, there are no reports of B. californicus colonizing citrus in SP, and our attempts to rear such species on citrus fruit (at $25 \pm 1^{\circ} \mathrm{C}$ ) were not successful (data not shown).

To our knowledge, this work is the first formal report of B. phoenicis sensu stricto in citrus in Brazil. Sánchez-Velázquez et al. (2015), in a recent survey in citrus orchards in this country, identified the prevalent $B$. yothersi and the less common $B$. papayensis species but not $B$. phoenicis sensu stricto in the production areas. The study was conducted in tropical regions, where most of the citrus is grown in Brazil and high temperatures are reached during several months of the year, favoring those mite species. Conversely, according to Beard et al. (2015), B. phoenicis sensu stricto was first identified in 1930s in the arecaceae plant Phoenix canariensis in a greenhouse in The Netherlands. Because the authors confirmed only a limited number of specimens as B. phoenicis sensu stricto from a few places (The Netherlands, the United States, and Costa Rica), it cannot be ruled out that the development of this mite species might be favored by cooler weather conditions. Interestingly enough, CL-N symptoms were identified only in marginal citrus production regions of Brazil, in a cooler climate zone associated with higher altitudes. This could partially explain the restricted dissemination of the B. phoenicis-transmitted viruses because, for plant rhabdoviruses, geographical distribution may be directly linked to that of their vectors due to a close interaction between them (Barandoc-Alviar et al. 2016; Kormelink et al. 2011).

Another difference between the newly characterized CiLV-N and the OFV-citrus from Mexico is their host ranges. The citrus strain of $\mathrm{OFV}$ is able to naturally infect at least seven citrus species, including sweet orange, grapefruit, mandarin, lemon, lime, sweet lime, and sour orange plants (Roy et al. 2015b). On the other hand, CiLV-N seems to have a narrow host range. Even though we have not made an extensive survey on citrus species, CiLV-N has been identified only in sweet orange plants, even when mandarin and lime are grown nearby, suggesting that it does not infect those hosts (data not shown). Kitajima et al. (1972) reported the presence of a CL-N-associated virus in grapefruit trees in SP but no further diseased grapefruit plants have been detected since. It should be noted, however, that Brazil is not a relevant producer of grapefruit and it is difficult to find such citrus species both in orchards and in backyards.

In addition to the natural sweet orange host, we were able to transmit CiLV-N using B. phoenicis sensu stricto mites from sweet orange to sweet orange plants as well as to the experimental host A. thaliana, as reported for CoRSV and ClCSV (Arena et al. 2017). Similar to what was observed for these viruses, the time of symptom appearance ranged from 8 to 10 days, and the symptoms appeared as localized lesions. However, CiLV-N induced the appearance of typical pinpoint lesions, smaller than those observed for the other two viruses (Arena et al. 2017). The infection of Arabidopsis by this virus opens new doors for understanding the interactions between this host, a CL-N-associated virus, and the Brevipalpus mite, as established for the CL-C pathosystem (Arena et al. 2016). In addition, it will allow the comparison between the responses of Arabidopsis to CL-associated viruses from the nuclear and cytoplasmic types belonging to viral genera that display contrasting molecular biology.

Comprehensively, our molecular and biological data show that CiLV-N should be assigned to a new species within the genus Dichorhavirus. We propose this species should be definitively named Citrus leprosis $\mathrm{N}$ dichorhavirus both because this is the first characterized dichorhavirus with citrus as its primary host and also due to historical priority, because this is the oldest circulating virus associated with citrus leprosis that can be currently detected in fields. Dietzgen et al. (2014) mentions that, because the Mexican CL-N virus is a strain of OFV, sequencing of other viruses causing CL-N should help to determine whether or not the acronym CiLV-N, previously used for the Mexican CL-N virus, should be abandoned. Here, we demonstrate that it should not.

\section{ACKNOWLEDGMENTS}

We thank V. M. Novelli, M. Bastianel, and J. D. De Negri (Centro de Citricultura Sylvio Moreira, SP, Brazil), G. Otero-Colina (Colegio de Postgraduados, Texcoco, Mexico), and W. Turizo-Álvarez (Universidad Nacional de Colombia, Bogotá, Colombia) for kindly providing biological samples used in this work; and P. Toledo for technical assistance. This work was partially supported by CNPq (375843/2012-4, 481771/2013-1, and 401564/2012-6) and FAPESP (2014/08458-9 and 2016/01960-6).

\section{LITERATURE CITED}

Afonso, C. L., Amarasinghe, G. K., Bányai, K., Bào, Y., Basler, C. F., Bavari, S., Bejerman, N., Blasdell, K. R., Briand, F.-X., Briese, T., Bukreyev, A., Calisher, C. H., Chandran, K., Chéng, J., Clawson, A. N., Collins, P. L., Dietzgen, R. G., Dolnik, O., Domier, L. L., Dürrwald, R., Dye, J. M., Easton, A. J., Ebihara, H., Farkas, S. L., Freitas-Astúa, J., Formenty, P., Fouchier, R. A. M., Fù, Y., Ghedin, E., Goodin, M. M., Hewson, R., Horie, M., Hyndman, T. H., Jiāng, D., Kitajima, E. W., Kobinger, G. P., Kondo, H., Kurath, G., Lamb, R. A., Lenardon, S., Leroy, E. M., Li, C.-X., Lin, X.-D., Liú, L., Longdon, B., Marton, S., Maisner, A., Mühlberger, E., Netesov, S. V., Nowotny, N., Patterson, J. L., Payne, S. L., Paweska, J. T., Randall, R. E., Rima, B. K., Rota, P., Rubbenstroth, D., Schwemmle, M., Shi, M., Smither, S. J., Stenglein, M. D., Stone, D. M., Takada, A., Terregino, C., Tesh, R. B., Tian, J.-H., Tomonaga, K., Tordo, N., Towner, J. S., Vasilakis, N., Verbeek, M., Volchkov, V. E., Wahl-Jensen, V., Walsh, J. A., Walker, P. J., Wang, D., Wang, L.-F., Wetzel, T., Whitfield, A. E., Xiè, J. T., Yuen, K.-Y., Zhang, Y.-Z., and Kuhn, J. H. 2016. Taxonomy of the order Mononegavirales: Update 2016. Arch. Virol. 161:2351-2360.

Arena, G. D., Ramos-González, P. L., Nunes, M. A., Alves, M. R., Camargo, L. E. A., Kitajima, E. W., Machado, M. A., and Freitas-Astua, J. 2016. Citrus leprosis virus $\mathrm{C}$ infection results in hypersensitive-like response, suppression of the JA/ET plant defense pathway and promotion of the colonization of its mite vector. Front. Plant Sci. 7:1757.

Arena, G. D., Ramos-González, P. L., Nunes, M. A., Jesus, C. C., Calegario, R. F., Kitajima, E. W., Novelli, V. M., Freitas-Astúa, J., Arena, G. D., Ramos-González, P. L., Nunes, M. A., Jesus, C. C., Calegario, R. F., Kitajima, E. W., Novelli, V. M., and Freitas-Astúa, J. 2017. Arabidopsis thaliana as a model host for Brevipalpus mite-transmitted viruses. Sci. Agric. 74:85-89.

Barandoc-Alviar, K., Badillo-Vargas, I. E., and Whitfield, A. E. 2016. Interactions between insect vectors and propagative plant viruses. Pages 133-180 in: Management of Insect Pests to Agriculture. H. Czosnek and G. Murad, eds. Springer International Publishing, Cham, Switzerland.

Bastianel, M., Novelli, V. M., Kitajima, E. W., Kubo, K. S., Bassanezi, R. B., Machado, M. A., and Freitas-Astúa, J. 2010. Citrus Leprosis: Centennial of an unusual mite-virus pathosystem. Plant Dis. 94:284-292.

Beard, J. J., Ochoa, R., Braswell, W. E., and Bauchan, G. R. 2015. Brevipalpus phoenicis (Geijskes) species complex (Acari: Tenuipalpidae)—A closer look. Zootaxa 3944:1-67.

Betley, J. N., Frith, M. C., Graber, J. H., Choo, S., and Deshler, J. O. 2002. A ubiquitous and conserved signal for RNA localization in chordates. Curr. Biol. 12:1756-1761.

Bitancourt, A. 1938. A mancha anular, uma nova doença do cafeeiro. O Biológico 4:404-405.

Bitancourt, A. 1940. A leprose dos citrus. O Biológico 6:39-45.

Bobot, T. da E., Franklin, E., Navia, D., Gasnier, T. R. J., Lofego, A. C., and de Oliveira, B. M. 2011. Mites (Arachnida, Acari) on Citrus sinensis L. Osbeck orange trees in the state of Amazonas, Northern Brazil. Acta Amazonica 41:557-566.

Chagas, C., Colariccio, A., and Harakava, R. 2006. Novos registros da leprose tipo nuclear (CiLV-N): Andradas (MG) e São Roque (SP). Fitopatol. Bras. 39:139.

Chenna, R., Sugawara, H., Koike, T., Lopez, R., Gibson, T. J., Higgins, D. G., and Thompson, J. D. 2003. Multiple sequence alignment with the Clustal series of programs. Nucleic Acids Res. 31:3497-3500.

Childers, C. C., Rodrigues, J. C. V., Derrick, K. S., Achor, D. S., French, J. V., Welbourn, W. C., Ochoa, R., and Kitajima, E. W. 2003a. Citrus leprosis and its status in Florida and Texas: Past and present. Exp. Appl. Acarol. 30: 181-202.

Childers, C. C., Rodrigues, J. C. V., and Welbourn, W. C. 2003b. Host plants of Brevipalpus californicus, B. obovatus, and B. phoenicis (Acari: Tenuipalpidae) and their potential involvement in the spread of viral diseases vectored by these mites. Exp. Appl. Acarol. 30:29-105.

Cruz-Jaramillo, J. L., Ruiz-Medrano, R., Rojas-Morales, L., López-Buenfil, J. A., Morales-Galván, O., Chavarín-Palacio, C., Ramírez-Pool, J. A., and Xoconostle-Cázares, B. 2014. Characterization of a proposed dichorhavirus 
associated with the citrus leprosis disease and analysis of the host response. Viruses 6:2602-2622.

Dietzgen, R. G., Kondo, H., Goodin, M. M., Kurath, G., and Vasilakis, N. 2017. The family Rhabdoviridae: Mono- and bipartite negative-sense RNA viruses with diverse genome organization and common evolutionary origins. Virus Res. 227:158-170.

Dietzgen, R. G., Kuhn, J. H., Clawson, A. N., Freitas-Astúa, J., Goodin, M. M., Kitajima, E. W., Kondo, H., Wetzel, T., and Whitfield, A. E. 2014. Dichorhavirus: A proposed new genus for Brevipalpus mite-transmitted, nuclear, bacilliform, bipartite, negative-strand RNA plant viruses. Arch. Virol. 159:607-619.

Doi, Y., Arai, K., and Yora, K. 1969. Ultrastructure of bacilliform virus found in Euonymus japonicum with mosaic and Cymbidium with ringspot. Ann. Phytopathol. Soc. Jpn. 35:388.

de Dominguez, F. S., Bernal, A., Childers, C. C., and Kitajima, E. W. 2001. First report of citrus leprosis virus in Panama. Plant Dis. 85:228.

Freitas-Astúa, J., Kitajima, E., and Bastianel, M. 2004. Identification of Citrus leprosis virus-nuclear type (CiLV-N) in sweet orange in the State of Rio Grande do Sul. Virus Rev. Res. 9:247.

Hartung, J. S., Roy, A., Fu, S., Shao, J., Schneider, W. L., and Brlansky, R. H. 2015. History and diversity of citrus leprosis virus recorded in herbarium specimens. Phytopathology 105:1277-1284.

Holmes, E. C. 2003. Error thresholds and the constraints to RNA virus evolution. Trends Microbiol. 11:543-546.

Jackson, A. O., Dietzgen, R. G., Goodin, M. M., Bragg, J. N., and Deng, M. 2005. Biology of plant rhabdoviruses. Annu. Rev. Phytopathol. 43:623660.

Kannan, S., Hui, J., Mazooji, K., Pachter, L., and Tse, D. 2016. Shannon: An information-optimal de novo RNA-Seq assembler. bioRxiv Article 39230.

Kitajima, E. W., and Alberti, G. 2014. Ultrastructural detection of cytoplasmic and nuclear types of Brevipalpus transmitted viruses. Part 7, Pages 173-192 in: Anatomy and Fine Structure of Bevipalpus Mites (Tenuipalpidae)Economically Important Plant Virus Vectors. Zoologica, Vol. 160. G. Alberti and E. W. Kitajima, eds. Schweizerbart Science Publishers, Stuttgart, Germany.

Kitajima, E. W., Blumenschein, A., and Costa, A. S. 1974a. Rodlike particles associated with ringspot symptoms in several orchid species in Brazil. J. Phytopathol. 81:280-286

Kitajima, E. W., Chagas, C. M., Harakava, R., Calegario, R. F., Freitas-Astúa, J., Rodrigues, J. C. V., and Childers, C. C. 2011. Citrus leprosis in Florida, USA, appears to have been caused by the nuclear type of citrus leprosis virus (CiLV-N). Virus Rev. Res. 16:1-14.

Kitajima, E. W., Chagas, C. M., and Rodrigues, J. C. V. 2003. Brevipalpustransmitted plant virus and virus-like diseases: Cytopathology and some recent cases. Exp. Appl. Acarol. 30:135-160.

Kitajima, E. W., Ferreira, P. T. O., Freitas-Astúa, J., and Machado, M. A. 2004. Ocorrência da leprose dos citros, tipo nuclear (CiLV-N), nos municípios paulistas de Monte Alegre do Sul e Amparo. Summa Phytopathol. 30:68.

Kitajima, E. W., Müller, G. W., Costa, A. S., and Yuki, W. 1972. Short, rodlike particles associated with Citrus leprosis. Virology 50:254-258.

Kitajima, E. W., and Nome, C. 1999. Microscopia electrónica em virologia vegetal. Pages 59-87 in: Métodos para detectar patógenos sistémicos. D. Docampo and S. Lenardón, eds. IFFIVE/INTA-JICA, Cordova, Argentina.

Kitajima, E. W., Rosillo, M. A., Portillo, M. M., Muller, G. W., and Costa, A. S. 1974b. Microscopia eletrônica de tecidos foliares de laranjeiras infectadas pela lepra explosiva da Argentina. Fitopatologia 9:55-56.

Knorr, L. C. 1968. Studies on the etiology of leprosis in citrus. Pages 332-341 in: Proc. 4th Conf. Int. Organ. Citrus. Virol. University of Florida Press, Gainesville.

Kondo, H., Chiba, S., Andika, I. B., Maruyama, K., Tamada, T., and Suzuki, N. 2013. Orchid fleck virus structural proteins $\mathrm{N}$ and $\mathrm{P}$ form intranuclear viroplasm-like structures in the absence of viral infection. J. Virol. 87:74237434.

Kondo, H., Maeda, T., Shirako, Y., and Tamada, T. 2006. Orchid fleck virus is a rhabdovirus with an unusual bipartite genome. J. Gen. Virol. 87:24132421.

Kondo, H., Maeda, T., and Tamada, T. 2003. Orchid fleck virus: Brevipalpus californicus mite transmission, biological properties and genome structure. Exp. Appl. Acarol. 30:215-223.

Kondo, H., Maruyama, K., Chiba, S., Andika, I. B., and Suzuki, N. 2014. Transcriptional mapping of the messenger and leader RNAs of orchid fleck virus, a bisegmented negative-strand RNA virus. Virology 452-453:166174

Kormelink, R., Garcia, M. L., Goodin, M., Sasaya, T., and Haenni, A.-L. 2011. Negative-strand RNA viruses: The plant-infecting counterparts. Virus Res. 162:184-202.

Kosugi, S., Hasebe, M., Tomita, M., and Yanagawa, H. 2009. Systematic identification of cell cycle-dependent yeast nucleocytoplasmic shuttling proteins by prediction of composite motifs. Proc. Natl. Acad. Sci. USA 106: 10171-10176.
Kubo, K. S., Freitas-Astúa, J., Machado, M. A., and Kitajima, E. W. 2009. Orchid fleck symptoms may be caused naturally by two different viruses transmitted by Brevipalpus. J. Gen. Plant Pathol. 75:250-255.

Kumar, S., Stecher, G., and Tamura, K. 2016. MEGA7: Molecular Evolutionary Genetics Analysis version 7.0 for bigger datasets. Mol. Biol. Evol. 33:1870-1874

la Cour, T., Kiemer, L., Mølgaard, A., Gupta, R., Skriver, K., and Brunak, S. 2004. Analysis and prediction of leucine-rich nuclear export signals. Protein Eng. Des. Sel. 17:527-536.

Le, S. Q., and Gascuel, O. 2008. An improved general amino acid replacement matrix. Mol. Biol. Evol. 25:1307-1320.

León, G., Roy, A., Choudhary, N., and Brlansky, R. 2014. Citrus leprosis virus cytoplasmic type 2 (CiLV-C2) detection in Meta and Casanare States. Corpoica Cienc. Tecnol. Agropecu. 15:207-217.

Locali, E. C., Freitas-Astua, J., de Souza, A. A., Takita, M. A., Astua-Monge, G., Antonioli, R., Kitajima, E. W., and Machado, M. A. 2003. Development of a molecular tool for the diagnosis of leprosis, a major threat to citrus production in the Americas. Plant Dis. 87:1317-1321.

Locali-Fabris, E. C., Freitas-Astúa, J., and Machado, M. A. 2012. Genus Cilevirus. Pages 1139-1142 in: International Committee on Taxonomy of Viruses, IX Report. A. King, M. Adams, E. Carstens, and E. Lefkowitz, eds. Elsevier/Academic Press, London.

Mann, K. S., and Dietzgen, R. G. 2014. Plant rhabdoviruses: New insights and research needs in the interplay of negative-strand RNA viruses with plant and insect hosts. Arch. Virol. 159:1889-1900.

Melzer, M. J., Sether, D. M., Borth, W. B., and Hu, J. S. 2012. Characterization of a virus infecting Citrus volkameriana with citrus leprosis-like symptoms. Phytopathology 102:122-127.

Okonechnikov, K., Golosova, O., Fursov, M., and the UGENE team. 2012. Unipro UGENE: A unified bioinformatics toolkit. Bioinformatics 28: 1166-1167.

Petersen, T. N., Brunak, S., von Heijne, G., and Nielsen, H. 2011. SignalP 4.0: Discriminating signal peptides from transmembrane regions. Nat. Methods 8:785-786

Poch, O., Blumberg, B. M., Bougueleret, L., and Tordo, N. 1990. Sequence comparison of five polymerases ( $\mathrm{L}$ proteins) of unsegmented negativestrand RNA viruses: Theoretical assignment of functional domains. J. Gen. Virol. 71:1153-1162.

Ramalho, T. O., Figueira, A. R., Sotero, A. J., Wang, R., Geraldino Duarte, P. S., Farman, M., and Goodin, M. M. 2014. Characterization of Coffee ringspot virus-Lavras: A model for an emerging threat to coffee production and quality. Virology 464-465:385-396.

Ramos-González, P. L., Chabi-Jesus, C., Guerra-Peraza, O., Breton, M. C., Arena, G. D., Nunes, M. A., Kitajima, E. W., Machado, M. A., and Freitas-Astúa, J. 2016a. Phylogenetic and molecular variability studies reveal a new genetic clade of Citrus leprosis virus C. Viruses 8:153.

Ramos-González, P. L., Sarubbi-Orue, H., Gonzales-Segnana, L., Chabi-Jesus, C., Freitas-Astúa, J., and Kitajima, E. W. 2016b. Orchid fleck virus infecting orchids in Paraguay: First report and use of degenerate primers for its detection. J. Phytopathol. 164:342-347.

Rodrigues, J. C. V., Kitajima, E. W., Childers, C. C., and Chagas, C. M. 2003. Citrus leprosis virus vectored by Brevipalpus phoenicis (Acari: Tenuipalpidae) on citrus in Brazil. Exp. Appl. Acarol. 30:161-179.

Roy, A., Choudhary, N., Guillermo, L. M., Shao, J., Govindarajulu, A., Achor, D., Wei, G., Picton, D. D., Levy, L., Nakhla, M. K., Hartung, J. S., and Brlansky, R. H. 2013a. A novel virus of the genus Cilevirus causing symptoms similar to citrus leprosis. Phytopathology 103:488-500.

Roy, A., Hartung, J. S., Schneider, W. L., Shao, J., Leon, M. G., Melzer, M. J., Beard, J. J., Otero-Colina, G., Bauchan, G. R., Ochoa, R., and Brlansky, R. H. 2015a. Role bending: Complex relationships between viruses, hosts, and vectors related to citrus leprosis, an emerging disease. Phytopathology 105:1013-1025

Roy, A., Leon, M. G., Stone, A. L., Schneider, W. L., Hartung, J., and Brlansky, R. H. 2014. First report of citrus leprosis virus nuclear type in sweet orange in Colombia. Plant Dis. 98:1162.

Roy, A., Stone, A., Otero-Colina, G., Wei, G., Choudhary, N., Achor, D., Shao, J., Levy, L., Nakhla, M. K., Hollingsworth, C. R., Hartung, J. S., Schneider, W. L., and Brlansky, R. H. 2013b. Genome assembly of citrus leprosis virus Nuclear type reveals a close association with orchid fleck virus. Genome Announc. 1:e00519-13.

Roy, A., Stone, A. L., Shao, J., Otero-Colina, G., Wei, G., Choudhary, N., Achor, D., Levy, L., Nakhla, M. K., Hartung, J. S., Schneider, W. L., and Brlansky, R. H. 2015b. Identification and molecular characterization of nuclear citrus leprosis virus, a member of the proposed Dichorhavirus genus infecting multiple citrus species in Mexico. Phytopathology 105:564-575.

Salinas-Vargas, D., Santillán-Galicia, M. T., Guzmán-Franco, A. W., Hernández-López, A., Ortega-Arenas, L. D., and Mora-Aguilera, G. 2016. Analysis of genetic variation in Brevipalpus yothersi (Acari: Tenuipalpidae) populations from four species of citrus host plants. PLoS One 11:e0164552. 
Salinas-Vargas, D., Santillán-Galicia, M. T., Valdez-Carrasco, J., Mora-Aguilera, G., Atanacio-Serrano, Y., and Romero-Pescador, P. 2013. Species composition and abundance of Brevipalpus spp. on different citrus species in Mexican orchards. Neotrop. Entomol. 42:419-425.

Sánchez-Velázquez, E. J., Santillán-Galicia, M. T., Novelli, V. M., Nunes, M. A., Mora-Aguilera, G., Valdez-Carrasco, J. M., Otero-Colina, G., and Freitas-Astúa, J. 2015. Diversity and genetic variation among Brevipalpus populations from Brazil and Mexico. PLoS One 10:e0133861.

Simmonds, P., Adams, M. J., Benkő, M., Breitbart, M., Brister, J. R., Carstens, E. B., Davison, A. J., Delwart, E., Gorbalenya, A. E., Harrach, B., Hull, R., King, A. M. Q., Koonin, E. V., Krupovic, M., Kuhn, J. H., Lefkowitz, E. J., Nibert, M. L., Orton, R., Roossinck, M. J., Sabanadzovic, S., Sullivan, M. B., Suttle, C. A., Tesh, R. B., van der Vlugt, R. A., Varsani, A., and Zerbini, F. M. 2017. Consensus statement: Virus taxonomy in the age of metagenomics. Nat. Rev. Microbiol. 15:161-168.

Untergasser, A., Cutcutache, I., Koressaar, T., Ye, J., Faircloth, B. C., Remm, M., and Rozen, S. G. 2012. Primer3-new capabilities and interfaces. Nucleic Acids Res. 40:e115.

Walker, P., Blasdell, K. R., Calisher, C. H., Dietzgen, R. G., Kondo, H., Kurath, G., Longdon, B., Stone, D. M., Tesh, R. B., Tordo, N., Vasilakis, N., and Whitfield, A. E. 2014. Create 2 new species, Orchid fleck dichorhavirus and Coffee ringspot dichorhavirus, in a new genus, Dichorhavirus, in the family Rhabdoviridae. ICTV [International Committee for Taxonomy of Viruses] Proposal (Taxoprop) No. 2014.003a-dV. http://www. ictvonline.org/proposals/2014.003a-dV.A.v3.Dichorhavirus.pdf

Walker, P. J., Firth, C., Widen, S. G., Blasdell, K. R., Guzman, H., Wood, T. G., Paradkar, P. N., Holmes, E. C., Tesh, R. B., Vasilakis, N., Holmes, E., King, A., Adams, M., Carstens, E., Lefkowitz, E., Lauber, C., Goeman, J., Mdel, C. P., Nga, P., Snijder, E., Belshaw, R., Pybus, O., Rambaut, A., Steinhauer, D., Domingo, E., Holland, J., Drake, J., Charlesworth, B., Charlesworth, D., Crow, J., Holmes, E., Eigen, M., Chirico, N., Vianelli, A., Belshaw, R., Belshaw, R., Gardner, A., Rambaut, A., Pybus, O., Nga, P., Parquet, M. del C., Lauber, C., Parida, M., Nabeshima, T., Snijder, E., Bredenbeek, P., Dobbe, J., Thiel, V., Ziebuhr, J., Gorbalenya, A., Enjuanes, L., Ziebuhr, J., Snijder, E., Kuzmin, I., Novella, I., Dietzgen, R., Padhi, A., Rupprecht, C., Walker, P., Dietzgen, R., Joubert, D., Blasdell, K., Lozano, R., Naghavi, M., Foreman, K., Lim, S., Shibuya, K., Dietzgen, R., Calisher, C., Kurath, G., Kuzman, I., Rodriguez, L., King, A., Adams, M., Carstens, E., Lefkowitz, E., Wang, Y., Walker, P., Allison, A., Mead, D., Palacios, G., Tesh, R., Holmes, E., Simon-Loriere, E., Holmes, E., Walker, P., Byrne, K., Riding, G., Cowley, J., Wang, Y., McWilliam, S., Kongsuwan, K., Cowley, J., Byrne, K., Walker, P., Spiropoulou, C., Nichol, S., Peluso, R.,
Richardson, J., Talon, J., Lock, M., Ledermann, J., Zeidner, N., Borland, E., Mutebi, J., Lanciotti, R., Coffey, L., Page, B., Greninger, A., Herring, B., Russell, R., Diniz, J., Nunes, M., da Rosa, A. T., Cruz, A., de Souza, W., Nieva, J., Madan, V., Carrasco, L., Vasilakis, N., Castro-Llanos, F., Widen, S., Aguilar, P., Guzman, H., Blasdell, K., Voysey, R., Bulach, D., Joubert, D., Tesh, R., Blasdell, K., Voysey, R., Bulach, D., Trinidad, L., Tesh, R., Wang, Y., McWilliam, S., Cowley, J., Walker, P., Gubala, A., Davis, S., Weir, R., Melville, L., Cowled, C., Gubala, A., Proll, D., Barnard, R., Cowled, C., Crameri, S., Gubala, A., Davis, S., Weir, R., Melville, L., Cowled, C., Joubert, D., Blasdell, K., Audsley, M., Trinidad, L., Monaghan, P., Vasilakis, N., Widen, S., Mayer, S., Seymour, R., Wood, T., Springfeld, C., Darai, G., Cattaneo, R., Quan, P., Williams, D., Johansen, C., Jain, K., Petrosov, A., Allison, A., Palacios, G., da Rosa, A. T., Popov, V., Lu, L., Firth, A., Brierley, I., Chenik, M., Chebli, K., Blondel, D., Jayakar, H., Whitt, M., Nagai, Y., Kato, A., Herman, R., Hatfield, D., Oroszlan, S., Bourhy, H., Cowley, J., Larrous, F., Holmes, E., Walker, P., Kuzmin, I., Hughes, G., Rupprecht, C., Joubert, D., Rodriguez-Andres, J., Monaghan, P., Cummins, M., McKinstry, W., Rancurel, C., Khosravi, M., Dunker, A., Romero, P., Karlin, D., Wilson, G., Bertrand, N., Patel, Y., Hughes, J., Feil, E., Fischer, D., Eisenberg, D., An, H., Kim, G., Wu, K., Kang, C., Haglund, K., Forman, J., Krausslich, H., Rose, J., Gago, S., Elena, S., Flores, R., Sanjuan, R., Simon-Loriere, E., Holmes, E., Pagan, I., Ravkov, E., Smith, J., Nichol, S., Ceccaldi, P., Fayet, J., Conzelmann, K., Tsiang, H., Faber, M., Pulmanausahakul, R., Nagao, K., Prosniak, M., Rice, A., Pagan, I., Holmes, E., Simon-Loriere, E., Wertz, G., Moudy, R., Ball, L., Banerjee, A., Whelan, S., Barr, J., Wertz, G., Keese, P., Gibbs, A., Kuzmin, I., Wu, X., Tordo, N., Rupprecht, C., Bilsel, P., Nichol, S., Rodriguez, L., Pauszek, S., Bunch, T., Schumann, K., Chare, E., Gould, E., Holmes, E., Huang, A., Lazzarini, R., Keene, J., Schubert, M., Perrault, J., Li, Z., Yu, M., Zhang, H., Magoffin, D., Jack, P., Lauber, C., Gorbalenya, A., Lauber, C., Gorbalenya, A., Lauber, C., Gorbalenya, A., Gill, F., Slikas, B., Sheldon, F., Fleischer, R., Bolger, A., Lohse, M., Usadel, B., Simpson, J., Wong, K., Jackman, S., Schein, J., Jones, S., Langmead, B., Salzberg, S., Robinson, J., Thorvaldsdottir, H., Winckler, W., Guttman, M., Lander, E., Remmert, M., Biegert, A., Hauser, A., Soding, J., Hogenhout, S., Redinbaugh, M., Ammar, E., Edgar, R., Talavera, G., Castresana, J., Guindon, S., Dufayard, J., Lefort, V., Anisimova, M., and Hordijk, W. 2015. Evolution of genome size and complexity in the Rhabdoviridae. PLoS Pathog. 11:e1004664.

Whelan, S., and Goldman, N. 2001. A general empirical model of protein evolution derived from multiple protein families using a maximum-likelihood approach. Mol. Biol. Evol. 18:691-699. 